This item was submitted to Loughborough's Research Repository by the author.

Items in Figshare are protected by copyright, with all rights reserved, unless otherwise indicated.

\title{
Design, synthesis, in vitro characterization and preliminary imaging studies on fluorinated bile acid derivatives as PET tracers to study hepatic transporters
}

\section{PLEASE CITE THE PUBLISHED VERSION}

https://doi.org/10.1016/j.bmc.2016.12.008

\section{PUBLISHER}

(C) Elsevier

\section{VERSION}

AM (Accepted Manuscript)

\section{PUBLISHER STATEMENT}

This work is made available according to the conditions of the Creative Commons Attribution-NonCommercialNoDerivatives 4.0 International (CC BY-NC-ND 4.0) licence. Full details of this licence are available at: https://creativecommons.org/licenses/by-nc-nd/4.0/

\section{LICENCE}

CC BY-NC-ND 4.0

\section{REPOSITORY RECORD}

Testa, Andrea, Sergio Dall'Angelo, Marco Mingarelli, Andrea Augello, Lutz Schweiger, Andrew Welch, Charles S. Elmore, Pradeep Sharma, and Matteo Zanda. 2019. "Design, Synthesis, in Vitro Characterization and Preliminary Imaging Studies on Fluorinated Bile Acid Derivatives as PET Tracers to Study Hepatic Transporters". figshare. https://hdl.handle.net/2134/36724. 


\title{
Design, Synthesis, In Vitro Characterization and Preliminary Imaging Studies on Fluorinated Bile Acid Derivatives as PET Tracers to Study Hepatic Transporters
}

\author{
Andrea Testa, ${ }^{a}$ Sergio Dall'Angelo, ${ }^{a}$ Marco Mingarelli, ${ }^{a}$ Andrea Augello, ${ }^{a}$ Lutz Schweiger, ${ }^{a}$ \\ Andy Welch, ${ }^{a}$ Charles S. Elmore, ${ }^{b}$ Pradeep Sharma, ${ }^{c, *}$ Matteo Zanda ${ }^{\mathrm{a}, \mathrm{d}, *}$ \\ a University of Aberdeen, Kosterlitz Centre for Therapeutics and John Mallard Scottish P.E.T. Centre, \\ Foresterhill, Aberdeen, AB25 2ZD (UK) \\ ${ }^{\mathrm{b}}$ Isotope Chemistry, Drug Safety and Metabolism, AstraZeneca R\&D, Pepparedsleden 1, 43150 Mölndal \\ (Sweden) \\ c Safety and ADME Modeling, DSM, AstraZeneca R\&D, Cambridge, CB4 OWG, UK \\ ${ }^{d}$ C.N.R. - I.C.R.M., via Mancinelli 7, 20131 Milan (Italy)
}

\section{ABSTRACT}

With the aim of identifying a fluorinated bile acid derivative that could be used as $\left[{ }^{18} \mathrm{~F}\right]$-labeled Positron Emission Tomography (PET) tracer for imaging the in vivo functioning of liver transporter proteins, and particularly of OATP1B1, three fluorinated bile acid triazole derivatives of cholic, deoxycholic and lithocholic acid (CATD, DCATD and LCATD 4a-c, respectively) were synthesized and labeled with tritium. In vitro transport properties were studied with cell-based assays to identify the best substrate for OATP1B1. In addition, the lead compound, LCATD (4c), was tested as a substrate of other liver uptake transporters OATP1B3, NTCP and efflux transporter BSEP to evaluate its specificity of liver transport. The results suggest that $4 \mathrm{c}$ is a good substrate of OATP1B1 and NTCP, whereas it is a poor substrate of OATP1B3. The efflux transporter BSEP also appears to be involved in the excretion of $\mathbf{4 c}$ from hepatocytes. The automated radiosynthesis of $\left[{ }^{18} \mathrm{~F}\right]-\mathbf{4 c}$ was accomplished in a multi-GBq scale and a pilot imaging experiment in a wild type rat was performed after i.v. administration to assess the biodistribution and clearance of the tracer. PET imaging revealed that radioactivity was primarily located in the liver ( $t_{\max }=75$ seconds) and cleared exclusively through the bile, thus allowing to image the hepatobiliary excretion of bile acids in the animal model. These findings suggest that $\left[{ }^{18} \mathrm{~F}\right]-$ LCATD $4 \mathbf{c}$ is a promising PET probe for the evaluation of hepatic transporters OATP1B1, NTCP and BSEP activity with potential for studying drug-drug interactions and drug-induced toxicity involving these transporters.

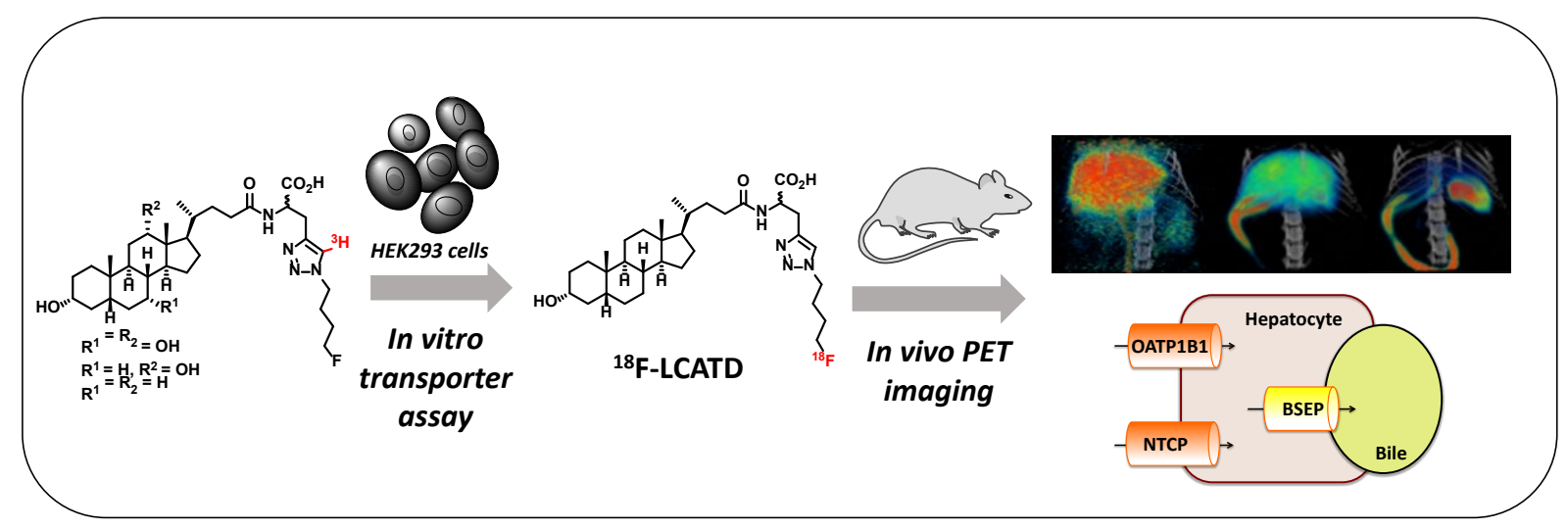

KEY WORDS: Fluorine, bile acids, liver transporters, PET imaging, tritium, preclinical study, click chemistry, clearance 


\section{INTRODUCTION}

Hepatic transporter proteins mediate the transport of many molecules through the hepatocyte, from the blood stream into the bile. Among the membrane transporters expressed on the basolateral membrane of hepatocytes, OATP1B1, OATP1B3 and NTCP play an important role in the uptake of both xenobiotics - such as drugs and their metabolites - and endogenous compounds - such as bile acids and bilirubin. ${ }^{1-3}$ Alteration of the functionality of these transporters may affect distribution and clearance of drugs and cause accumulation of toxic endogenous compounds in the blood. ${ }^{4}$ Canalicular transporters such as MATE1, MRP2, BCRP, BSEP and P-gp (MDR1/3), expressed on the apical membrane of hepatocytes, mediate the biliary excretion of drugs, drug metabolites and endogenous compounds. Inhibition of the canalicular efflux transporters can result in the accumulation of toxic metabolites in the hepatocyte, causing drug induced liver disease. ${ }^{5}$ Among the uptake transporters, the organic anion transporter polypeptide OATP1B1 (SLCO1B1, also called OATPC) is a particularly important liver specific transporter involved in the hepatic uptake of a wide range of clinically relevant drugs. ${ }^{1,6}$ According to recent studies on the absolute quantitative determination of the amount of transporters in the human liver, OATP1B1 is the most abundant uptake transporter. ${ }^{7}$ OATP1B1 downregulation, inhibition or genetic polymorphism may lead to inter-individual pharmacokinetic alterations and potential drug-drug interactions (DDIs). ${ }^{8}$ Conversely, the sodium taurocholate co-transporting polypeptide NTCP, (SLC1OA1), appears to be involved in the uptake of a relatively small number of clinically used drugs, but inhibition of NTCP can be a contributing factor to DDIs and a reduced NTCP activity or expression can result in a depressed bile acid uptake leading to cholestasis and hyperbilirubinemia. ${ }^{3,9,10}$ On the other hand, the efflux transporter BSEP (bile salt export pump, $A B C B 11$ ), mediates the excretion of bile acid salts from the apical membrane of hepatocytes to the bile canaliculi. ${ }^{9,11}$ Reduced activity of this transporter can be involved in drug induced liver injury caused by the accumulation of toxic bile acids in hepatocytes. ${ }^{12-14}$ Imaging of hepatic transporters activity has produced interesting data that contributed to increase the understanding of DDI's pharmacokinetics and proved the role of membrane transporters in drug distribution and disposition of some important clinically used drugs. Recently, review articles have been published which provide extensive information on general aspects, such as ideal criteria of Positron Emission Tomography/Computed Tomography (PET/CT) probes, design of hepato-selective PET probes, case studies, strengths and weaknesses of PET in imaging of transporters. ${ }^{15}$ PET tracers which are actively transported across cellular membranes can be used as probes to study membrane transport in vivo by imaging the tracer's uptake. In principle, any transport inhibition of the tracer would alter its in vivo distribution, which in turn could be used to determine the DDI potential of investigational drugs capable of inhibiting the tracer's transport pathways mediated by the transporter protein(s) involved. Bile acids - which are endogenous compounds synthesized in the liver as final products of cholesterol metabolism and excreted in the bile of vertebrates - are obvious substrates of these important transporters, and have been extensively employed as probe compounds to study physiological and pathological conditions related to the hepatobiliary transport. ${ }^{16-19}$

In this paper we report the design and synthesis of three fluorinated bile acid derivatives $4 a-c$ as prospective PET tracers for the imaging of OATP1B1/1B3, NTCP and BSEP activity in vivo. These compounds were labeled with tritium and assayed for in vitro transport properties. Based on the in vitro tests results, the lead compound LCATD (4c) was selected as candidate PET tracer and a fully automated radiosynthesis of $\left[{ }^{18} \mathrm{~F}\right]-4 \mathrm{c}$, suitable for producing the tracer in multi-GBq scale, was developed. Finally, a pilot imaging experiment was performed in a rat to prove that the PET tracer $\left[{ }^{18} \mathrm{~F}\right]-\mathbf{4 c}$ is hepatocyte-directed and excreted only through the bile.

\section{RESULTS}




\subsection{Synthesis of unlabeled and tritiated bile acid derivatives.}

The "cold" compounds CATD, DCATD and LCATD (4a-c) were synthesized respectively from cholic acid $\mathbf{1 a}$, deoxycholic acid $\mathbf{1 b}$ and lithocholic acid $\mathbf{1} \mathbf{c}$, which were reacted with racemic propargyl-glycine methyl ester and HATU in the presence of diisopropylethylamine. Propargyl-glycine-conjugated bile acids $2 a-c$ were isolated in good yields $(>82 \%)$ as diastereomeric mixtures by flash column chromatography (FCC). Compounds $\mathbf{2 a - c}$ were then reacted with 1-azido-4-fluorobutane (obtained in turn from 1-bromo-4-fluorobutane and sodium azide in DMF) in the copper-mediated alkyne-azide cycloaddition (CUAAC) to give triazoles 3a-c in high yields and with complete regiocontrol. ${ }^{20}$ Ester function deprotection of 3a-c with $2 \mathrm{M} \mathrm{KOH}$ in methanol solution gave quantitative yield of bile acidtriazole derivatives 4a-c as inseparable mixtures of two diasteroisomers (Scheme 1). Unsuccessful attempts were made for separating the diastereomers by flash chromatography.

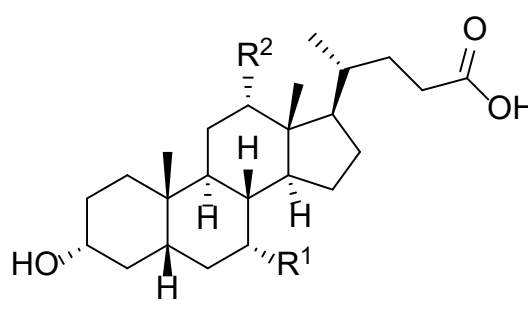

1a: $\mathrm{R}^{1}=\mathrm{R}_{2}=\mathrm{OH}$

1b: $\mathrm{R}^{1}=\mathrm{H}, \mathrm{R}_{2}=\mathrm{OH}$

1c: $R^{1}=R_{2}=H$

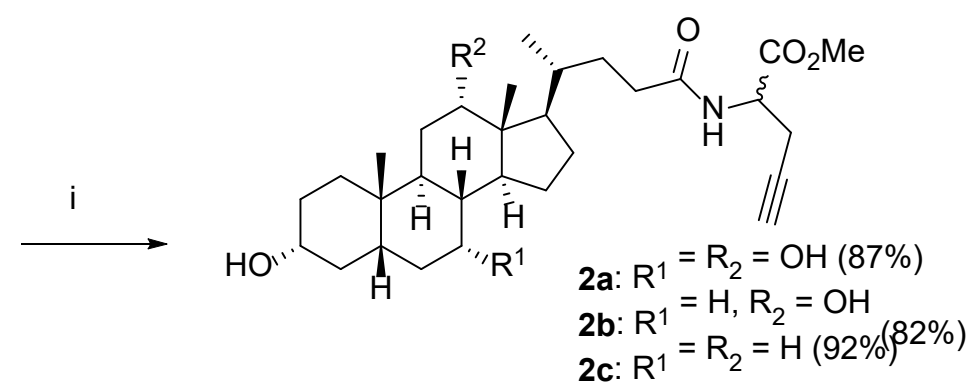

ii

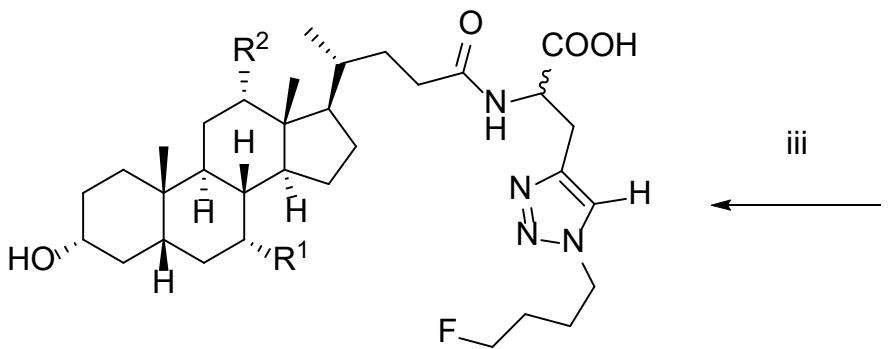

4a: CATD: $\mathrm{R}^{1}=\mathrm{R}_{2}=\mathrm{OH}(98 \%)$

4b: DCATD: $\mathrm{R}^{1}=\mathrm{H}, \mathrm{R}_{2}=\mathrm{OH}(98 \%)$

4c: LCATD: $\mathrm{R}^{1}=\mathrm{R}_{2}=\mathrm{H}(98 \%)$<smiles>C#CC1CCCCC1</smiles>

Scheme 1. Reagents and conditions: i): propargylglycine methyl ester, HATU, DIPEA, DCM, r.t. $3 \mathrm{hr}$; ii): 1-azido-4fluorobutane, $\mathrm{CuSO}_{4}$, Sodium Ascorbate in t-BuOH/$/ \mathrm{H}_{2} \mathrm{O}$, r.t. 24 h; iii): $2 \mathrm{M}$ aqueous $\mathrm{KOH}$ in methanol, r.t. $15 \mathrm{~min}$.

Tritium labelling was achieved from the corresponding iodoalkynes 5 a-c as previously described for $\left[{ }^{3} \mathrm{H}\right]$-CATD $4 a,{ }^{21}$ affording the labeled compounds in $>99.8 \%$ radiochemical purity and specific activity of 19.5-23.2 $\mathrm{Ci} \mathrm{mmol}^{-1}$ (Scheme 2). 


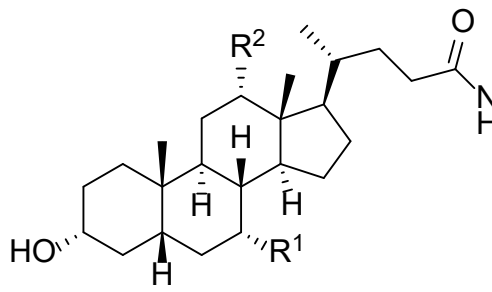

2a: $\mathrm{R}^{1}=\mathrm{R}_{2}=\mathrm{OH}$

2b: $R^{1}=H, R_{2}=O H$

2c: $R^{1}=R_{2}=H$

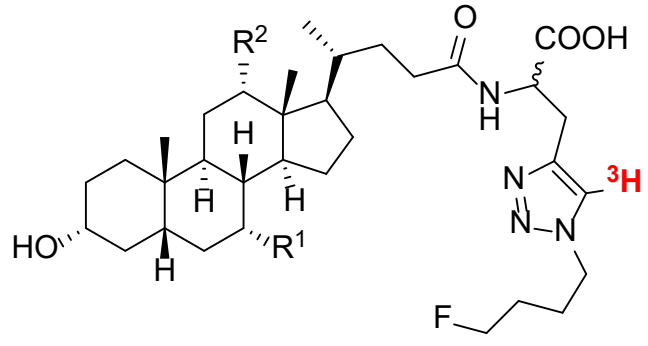

$\left[{ }^{3} \mathrm{H}\right]-4 \mathrm{a}$, CATD: $\mathrm{R}^{1}=\mathrm{R}_{2}=\mathrm{OH}$

$\left[{ }^{3} \mathrm{H}\right]-4 b$, DCATD: $\mathrm{R}^{1}=\mathrm{H}, \mathrm{R}_{2}=\mathrm{OH}$

$\left[{ }^{3} \mathrm{H}\right]-4 \mathrm{c}$, LCATD: $\mathrm{R}^{1}=\mathrm{R}_{2}=\mathrm{H}$

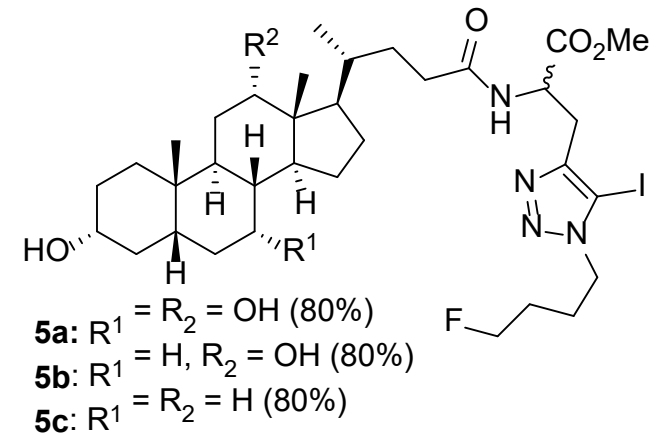

ii

iii<smiles>[R]C1C[C@H]2C[C@H](O)CC[C@]2(C)[C@H]2CC[C@@H]3CCC[C@H]3[C@H]1[C@H]2[R]</smiles>

$\left[{ }^{3} \mathrm{H}\right]-3 \mathrm{a}: \mathrm{R}^{1}=\mathrm{R}_{2}=\mathrm{OH}$

$\left[{ }^{3} \mathrm{H}\right]-3 \mathbf{b}: \mathrm{R}^{1}=\mathrm{H}, \mathrm{R}_{2}=\mathrm{OH}$

$\left[{ }^{3} \mathrm{H}\right]-3 \mathrm{c}: \mathrm{R}^{1}=\mathrm{R}_{2}=\mathrm{H}$

Scheme 2. Reagents and conditions:i) N-iodomorpholine-hydrogen iodide, Cul, THF, r.t. 1 h; 1-azido-4-fluorobutane, Cul, $T E A$, r.t. 24 h; ii) $T_{2}$, Pd/C, TEA, EtOH, r.t., 1.5 h; iii) NaOH 5M, $\mathrm{H}_{2} \mathrm{O}$, r.t $2 \mathrm{hr}$ (radiochemical purity before purification 94\%).

\subsection{In Vitro uptake of compounds $\left[{ }^{3} \mathrm{H}\right]-4 \mathrm{a}-\mathrm{c}$ in HEK293 OATPB1 cells}

Cellular uptake of tritium labeled compounds $\left[{ }^{3} \mathrm{H}\right]-4 \mathrm{a}-\mathrm{c}$ was measured using monolayer cultures of human embryonic kidney cells (HEK293) transfected in order to overexpress the OATP1B1 transporter and HECK293-MOCK cells, e.g. the same human embryonic kidney cells but transfected with an empty vector, used as negative control.

$\left[{ }^{3} \mathrm{H}\right]-4 \mathrm{a}-\mathrm{c}(0.05 \mu \mathrm{M})$ uptake was found to be higher in HEK293-OATP1B1 cells than in HEK293-MOCK transfected cells. However, while the uptake of $\left[{ }^{3} \mathrm{H}\right]-4 \mathrm{a}$ in HEK293-OATP1B1 cells reached the plateau after the first four minutes of incubation, the uptake of $\left[{ }^{3} \mathrm{H}\right]-\mathbf{4 b}$ and $\left[{ }^{3} \mathrm{H}\right]-4 \mathrm{c}$ in HEK293-OATP1B1 cells increased linearly until the last investigated time point, i.e. sixteen minutes. The amount of $\left[{ }^{3} \mathrm{H}\right]-4 \mathrm{a}$ taken up into HEK293-OATP1B1 cells was about fifteen times lower than the amount of $\left[{ }^{3} \mathrm{H}\right]-\mathbf{4 b}$ and $\left[{ }^{3} \mathrm{H}\right]-4 \mathrm{c}$ (Fig 1). 
$4 a$
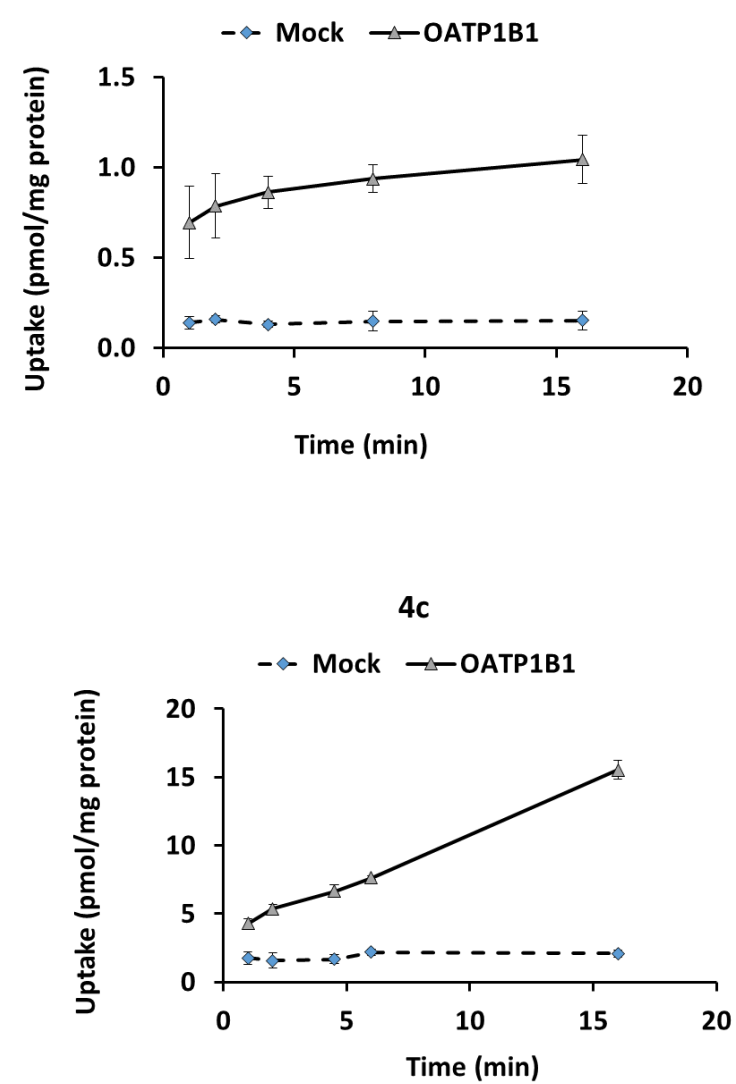

$4 b$

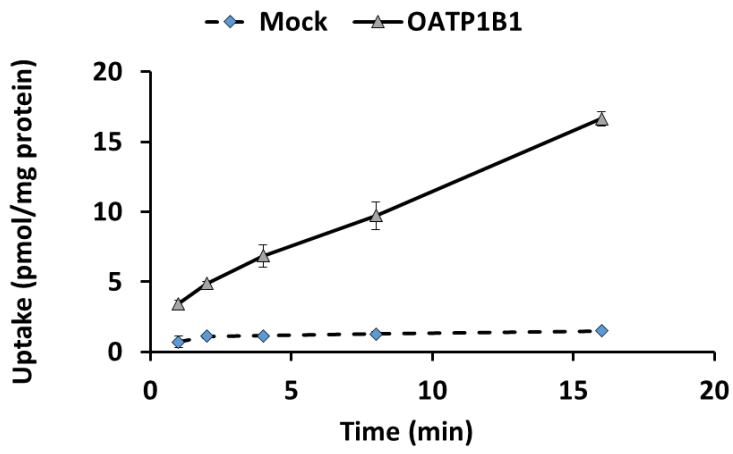

Figure 1. Time dependent uptake of probe substrates [ $\left.{ }^{3} \mathrm{H}\right]-4 a-c$ in HEK293-OATP1B1 and HEK293-MOCK transfected cells $(0.05 \mu M, n=3)$.

The uptake of $\left[{ }^{3} \mathrm{H}\right]-4 \mathrm{a}$ was significantly higher $(\mathrm{p}<0.05)$ in HEK293-OATP1B1 cells than in HEK293MOCK transfected cells at all the concentrations studied (Fig. 2). Uptake ratio for $\left[{ }^{3} \mathrm{H}\right]-4 a$ was between 2.0 and 1.3. The uptake of both $\left[{ }^{3} \mathrm{H}\right]-\mathbf{4 b}$ and $\left[{ }^{3} \mathrm{H}\right]-\mathbf{4} \mathrm{c}$ was also significantly higher $(p<0.01)$ in HEK293OATP1B1 cells than in HEK293-MOCK cells, and for the lower concentration studied ( 1 and $10 \mu \mathrm{M}$ ) the difference was significant $(p<0.001)$. Uptake ratios were found to be between 6.5 and 11.8 for $\left[{ }^{3} \mathrm{H}\right]$ 4b and between 2.0 and 7.3 for $\left[{ }^{3} \mathrm{H}\right]-4 \mathrm{c}$. 
4a

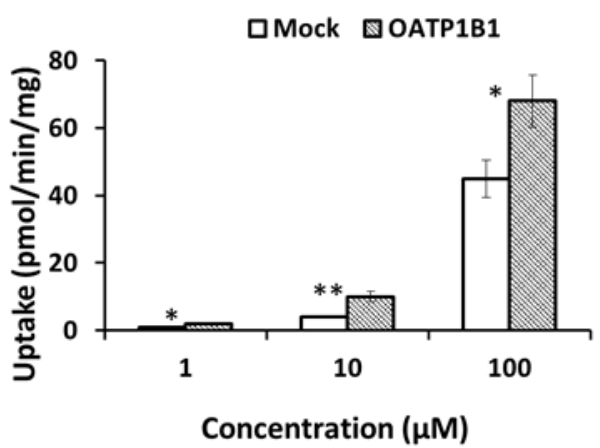

4c

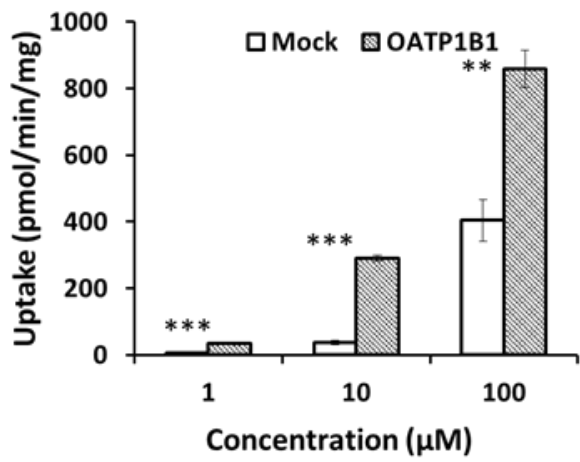

$4 \mathrm{~b}$

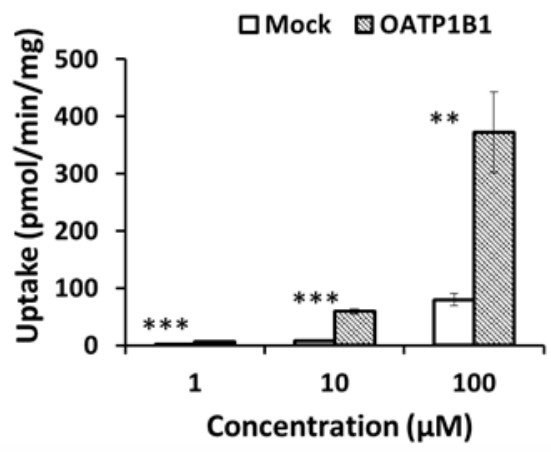

UPTAKE RATIOS

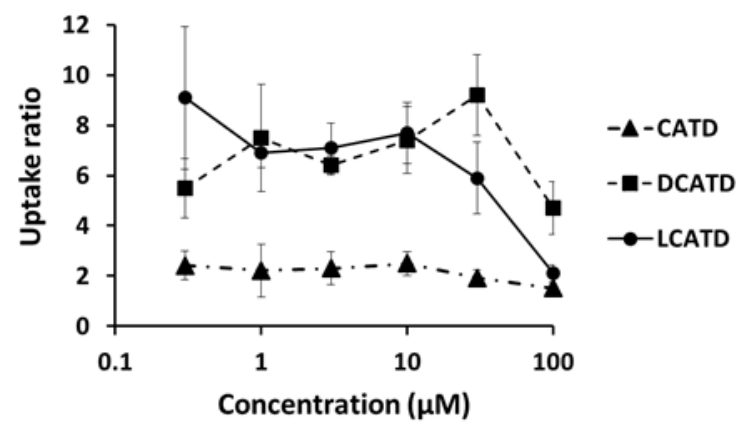

Figure 2. Concentration dependent uptake and uptake ratios ( \pm standard error) of probe compounds in HEK293-OATP1B1 and HEK293-MOCK transfected cell lines. Data of concentration dependent uptakeis expressed as mean $\pm S D(n=3) ; *^{* *}(p<$ $0.001) ;{ }^{* *}(p<0.01) ;{ }^{*}(p<0.05)$. Error bars in the uptake ratio represent the uncertainty in the data point calculated according to equation 5 .

The net OATP1B1-mediated substrate transport ( $\left.\mathrm{U}_{\mathrm{OATP1B} 1}\right)$ was found to be saturable for $\mathbf{4 c}$ and it could be described with a Michaelis-Menten equation (Fig. $3 C$ ), whereas full saturation could not be reached for $\mathbf{4 a , b}$ (Fig. $3 \mathrm{~A}, \mathrm{~B}$ ). For $\mathbf{4 c}$ the apparent $\mathrm{K}_{\mathrm{m}}$ and $\mathrm{V}_{\max }$, determined by plotting U UATP1B1 (pmol $\mathrm{min}^{-1} \mathrm{mg}^{-1}$ ) against substrate concentration, are reported in Table 1.

(A)

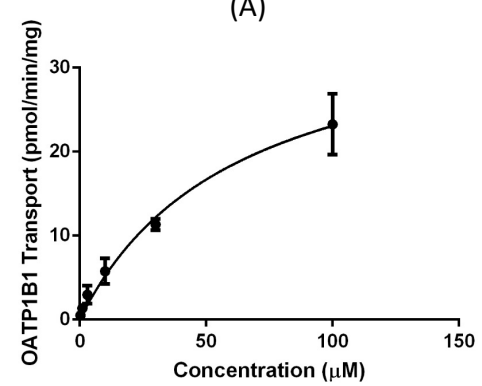

(B)

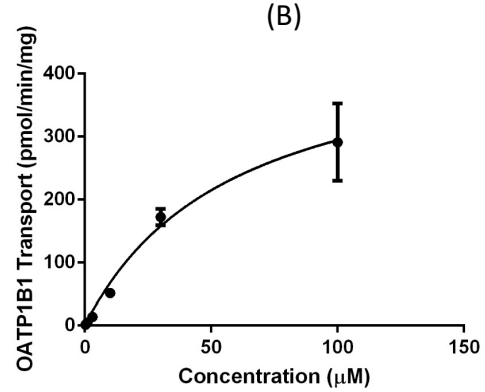

(C)

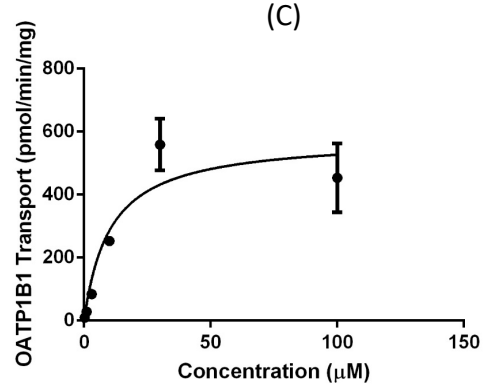

Figure 3. Kinetics of OATP1B1-mediated uptake of substrates (A) CATD 4a (B) DCATD $4 \boldsymbol{b}$ (C) LCATD 4c. Data is expressed as mean $\pm S D(n=3)$ and best fit curve is shown. 
The uptake of $\left[{ }^{3} \mathrm{H}\right]-\mathbf{4 a - c}(0.05 \mu \mathrm{M})$ was inhibited by rifamycin SV, a reference inhibitor of OATP1B1, at concentrations lower than $1 \mu \mathrm{M}$. However, the inhibition curve obtained for $\left[{ }^{3} \mathrm{H}\right]-4 \mathrm{a}$ was poorly defined due to the small inhibition window and hence it was impossible to calculate an $\mathrm{IC}_{50}$ value for rifamycin SV employing $\left[{ }^{3} \mathrm{H}\right]-\mathbf{4 a}$ as probe substrate. Conversely, using $\left[{ }^{3} \mathrm{H}\right]-\mathbf{4 b}, \mathbf{c}$ as probe substrates, $\mathrm{IC}_{50}$ values for rifamycin SV could be obtained $(0.13$ and $0.40 \mu \mathrm{M}$ respectively, see also Table 1 and Fig. 4).
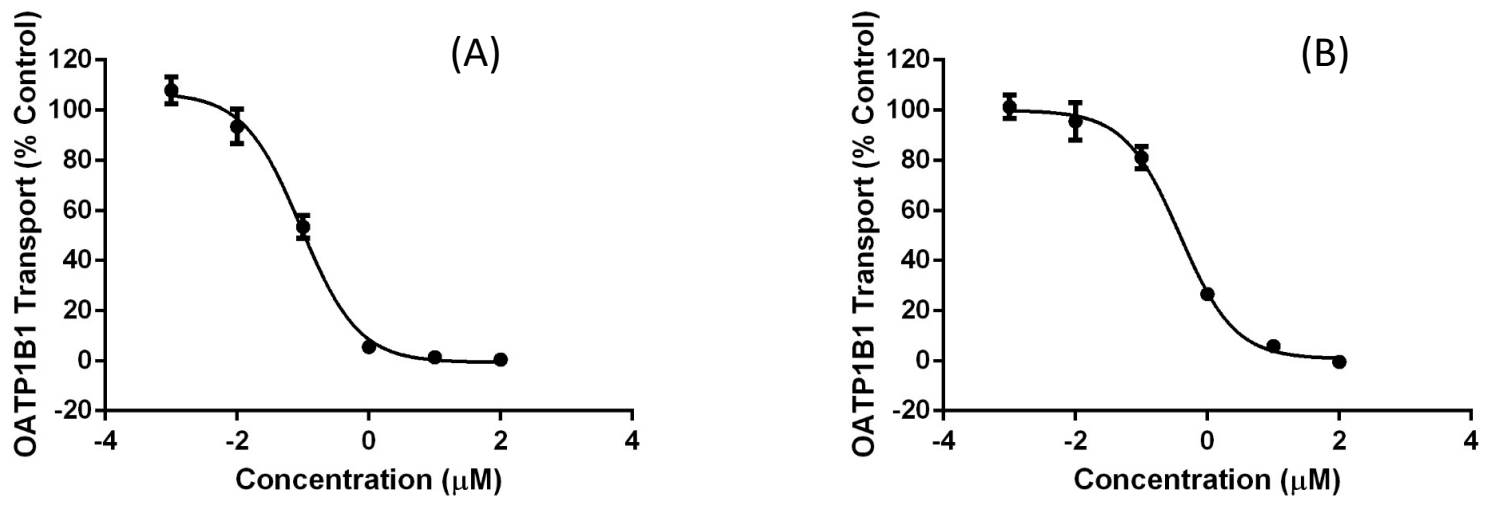

Figure 4. Concentration dependent OATP1B1-mediated uptake inhibition of (A) DCATD (4b) (B) LCATD (4c) by rifamycin SV. Data is expressed as mean $\pm S D(n=3)$ and best fit is shown. The $I C_{50}$ of CATD (4a) uptake inhibition by rifamycin SV could not be experimentally determined because of lack of full inhibition window since $4 a$ is not a good substrate of OATP1B1.

Concentrations of Rifamycin were 100, 10, 1, 0.1, 0.01, $0.001 \mu \mathrm{M}$, concentration of $4 a-c=0.05 \mu \mathrm{M}$.

Values of OATP1B1-intrinsic clearance (or intrinsic capacity) $\mathrm{CL}_{\text {int, } \mathrm{OATP1B1}}$ and passive diffusion clearance $\mathrm{CL}_{\text {diff }}$ obtained for $\mathbf{4 c}$ are reported in Table 1 along with those obtained in the same cells and - as reported previously by our group ${ }^{6}$ - for some well-known OATP1B1 probe compounds: estradiol-17$\beta$-glucuronide, pravastatin and pitavastatin. Since the OATP1B1 mediated transport of $\mathbf{4} \mathbf{c}$ is similar to that of these OATP1B1 probes (Table 1), this compound was selected as potential PET tracer, and its transport properties were further investigated.

\begin{tabular}{|c|c|c|c|c|c|c|}
\hline $\begin{array}{l}\text { Probe } \\
\text { compound }\end{array}$ & $\mathrm{K}_{\mathrm{m}}(\mu \mathrm{M})$ & $\begin{array}{l}V_{\max }(p m o l \\
\left.\min ^{-1} \mathrm{mg}^{-1}\right)\end{array}$ & $\begin{array}{c}\mathrm{IC}_{50} \\
\text { Rifamycin } \\
\mathrm{SV}(\mu \mathrm{M})\end{array}$ & $\begin{array}{c}\mathrm{CL}_{\text {int, OATP1B1 }} \\
\left(\mu \mathrm{L} \mathrm{min}^{-1}\right. \\
\left.\mathrm{mg}^{-1}\right)\end{array}$ & $\begin{array}{c}\mathrm{CL}_{\text {diff }} \\
\left(\mu \mathrm{L} \min ^{-1}\right. \\
\left.\mathrm{mg}^{-1}\right)\end{array}$ & $\begin{array}{c}\text { Ratio } \\
\left(\mathrm{CL}_{\text {int, OATP1B1 }}\right. \\
\left./ \mathrm{CL}_{\text {diff }}\right)\end{array}$ \\
\hline$\left[{ }^{3} \mathrm{H}\right]-4 \mathrm{c}$ (LCATD) & $10(6)$ & $581(101)$ & $0.40(0.05)$ & 58 & 0.64 & 91 \\
\hline $\begin{array}{l}\text { Estradiol-17- } \beta \text { - } \\
\text { glucuronide }\end{array}$ & $5.5(1.3)$ & $436(29)$ & $0.32(0.05)$ & 79 & 2.6 & 30 \\
\hline Pravastatin & $29(2.7)$ & $277(7)$ & $0.14(0.08)$ & 9.6 & 1.9 & 5 \\
\hline Pitavastatin & 1.3 & $373(21)$ & $0.27(0.01)$ & 287 & 13.6 & 21 \\
\hline
\end{tabular}

Table 1. Mean apparent kinetic parameters (and standard errors) for 4c in OATP1B1 substrate and inhibition assay obtained in this study compared with well-known OATP1B1 substrates as reported earlier in the same system. ${ }^{6}$

\subsection{Uptake of $\left[{ }^{3} \mathrm{H}\right]-$ LCATD (4c) in HEK293-OATP1B3 and CHO-NTCP cells}


The uptake of $\left[{ }^{3} \mathrm{H}\right]-4 \mathrm{c}$ was also studied in HEK293-OATP1B3 and NTCP expressing CHO-cells. In an HEK293-OATP1B3 cell line the uptake of $\left[{ }^{3} \mathrm{H}\right]-4 \mathrm{c}(0.05 \mu \mathrm{M})$ was higher than in the HEK293-MOCK transfected cell line up to 4 minutes of incubation. However, at 4 and 8 minutes of incubation the accumulation in HEK293-OATP1B3 was found not statistically relevant (Fig. 5A). Uptake ratios were between 2.0 and 2.4 (at concentrations 10 and $100 \mu \mathrm{M}$ respectively, Fig. 5B). An attempt to estimate $\mathrm{K}_{\mathrm{m}}$ by measuring the OATP1B3-mediated uptake failed as the saturation of the transporter was not reached at the highest concentration studied $(100 \mu \mathrm{M})$. In CHO-NTCP cells the uptake of $\left[{ }^{3} \mathrm{H}\right]-4 \mathrm{c}(0.05$ $\mu \mathrm{M})$ was found to be higher than in the control cell line and linear between 1 and 10 minutes of incubation and higher than in CHO-parental cell line at any time (Fig. 6). Uptake ratios were between 4 and 32. The net NTCP-mediated substrate transport $\left(\mathrm{U}_{\text {NTCP }}\right)$ was found to be saturable and followed a Michaelis-Menten kinetic (Fig. 7A). Apparent $K_{m}$ and $V_{\max }$, determined by plotting $U_{N T C P}$ (pmol min ${ }^{-1}$ $\mathrm{mg}^{-1}$ ) against substrate concentration were found to be $49 \mu \mathrm{M}$ and $2035 \mathrm{pmol} / \mathrm{min} / \mathrm{mg}$, respectively.
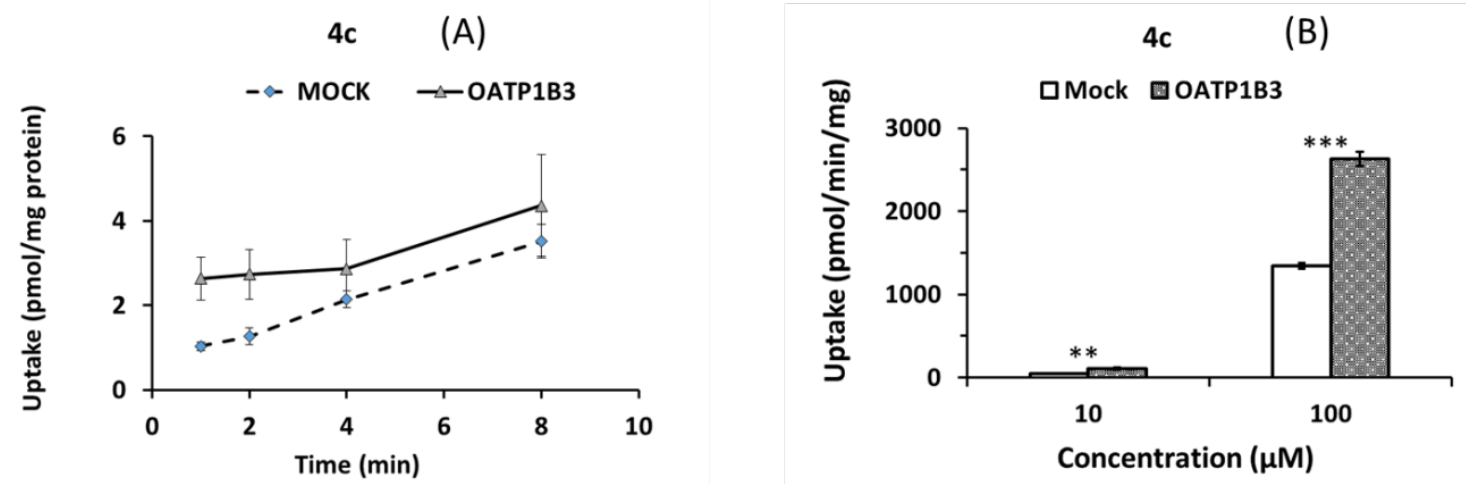

Figure 5. A) Time dependent uptake of [ $\left.{ }^{3} \mathrm{H}\right]-4 \mathrm{c}$ in HEK293-OATP1B3 and HEK293-MOCK cells. B) Uptake of [ $\left.{ }^{3} \mathrm{H}\right]-4 \mathrm{c}(10-100$ $\mu \mathrm{M})$ in HEK293-OATP1B3 and HEK293-MOCK cells. Data is expressed as mean $\pm S D(n=3) ; * * *(p<0.001) ;{ }^{* *}(p<0.01)$.

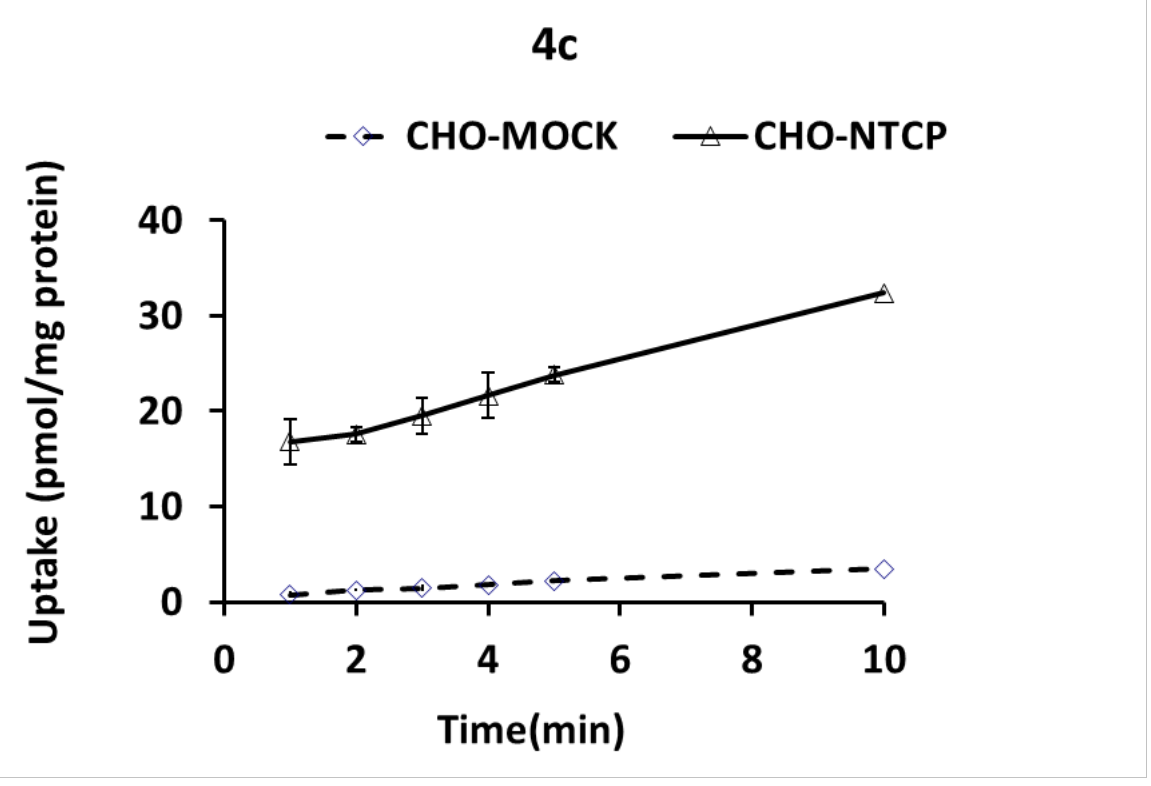

Figure 6. Time dependent uptake of [ $\left.{ }^{3} \mathrm{H}\right]-4 \mathrm{c}$ in $\mathrm{CHO}-\mathrm{NTCP}$ and $\mathrm{CHO}-\mathrm{MOCK}$ cells.

\subsection{Uptake of $\left[{ }^{3} \mathrm{H}\right]$-LCATD (4c) in BSEP inverted vesicles}


Transport of LCATD (4c) was determined in membrane vesicles transfected with BSEP transporter in the presence of ATP (total transport) and AMP (passive transport) over a concentration range 10-300 $\mu \mathrm{M}$. The ATP dependent transport was determined by deducting the transport in the presence of ATP to that in the presence of AMP and this reflected the BSEP mediate transporter activity (pmol/min/mg). Compound 4c exhibited concentration dependent BSEP mediated transport in BSEP transfected membrane vesicles (Fig. 7B).

(A)

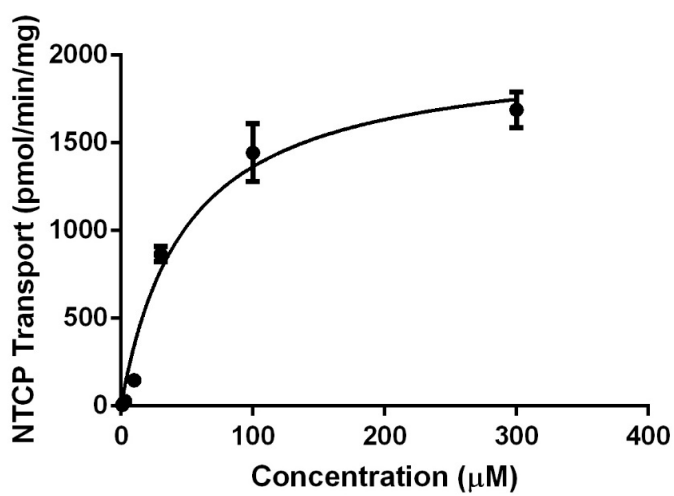

(B)

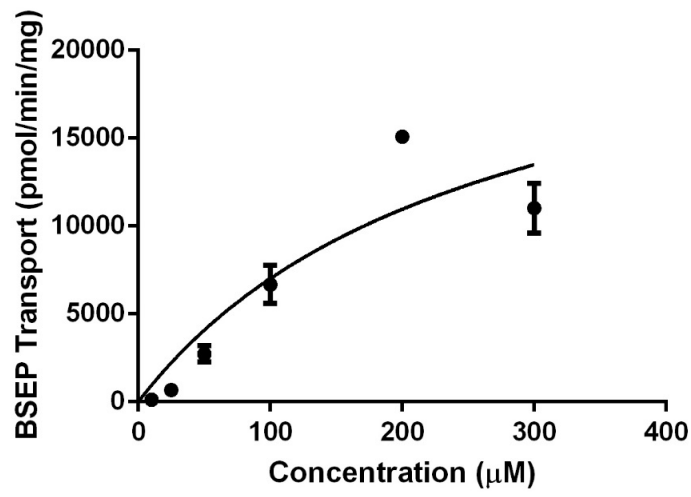

Figure 7. Kinetics of LCATD by bile transporters (A) NTCP-mediated uptake (B) BSEP-mediated efflux. Data is expressed as mean $\pm S D(n=3)$ and best fit curve is shown.

\subsection{Radiosynthesis of [ $\left.{ }^{18} \mathrm{~F}\right]$-LCATD-4c}

Compound $\mathbf{2 c}$ was acylated in $>98 \%$ yields with acetic anhydride in anhydrous pyridine to give the alkyne 6 which was reacted with 4-azidobutanol, copper sulphate and sodium ascorbate in a water/tert-butanol mixture (1:2) to give $\mathbf{7}$ in $90 \%$ yields. The mesylation was carried out in anhydrous dichloromethane in the presence of freshly distilled triethylamine and mesyl chloride, to give the radiofluorination precursor 8 . 


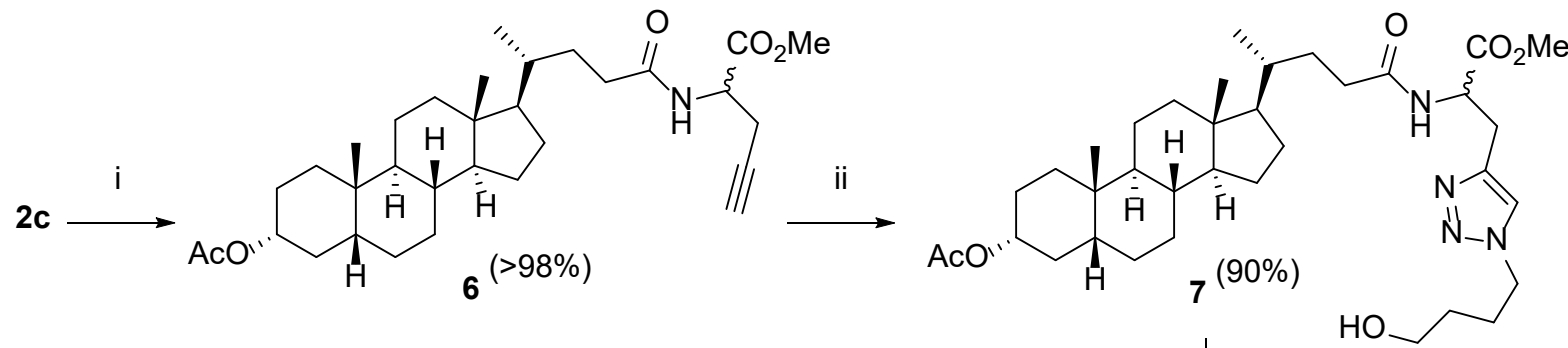

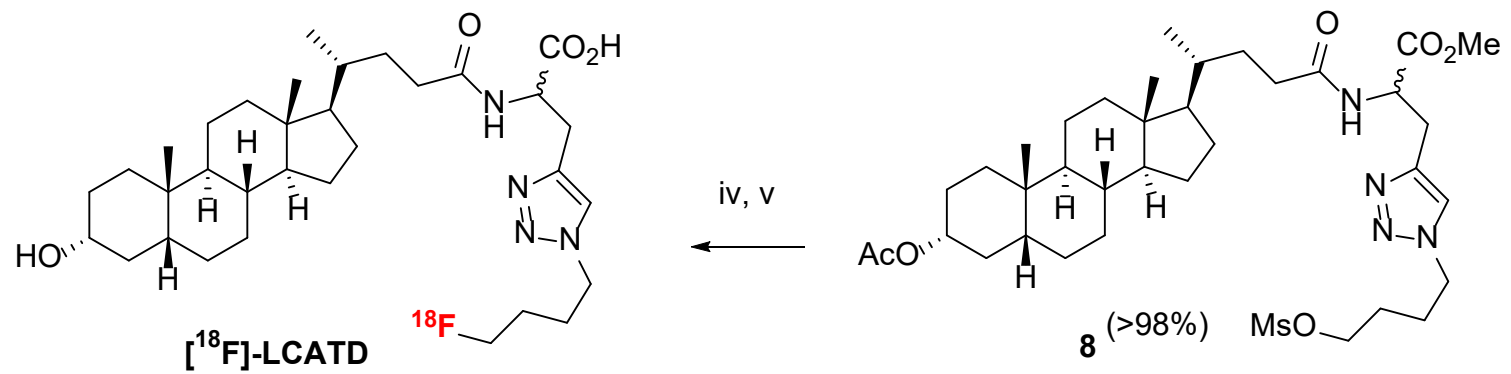

Scheme 3. Reagents and conditions: i) $\mathrm{Ac}_{2} \mathrm{O}$, in $\mathrm{Py}$, r.t., $3 \mathrm{~h}$; ii) 4-azidobutanol, $\mathrm{CuSO}_{4}$, sodium ascorbate in $\mathrm{tBuOH} / \mathrm{H}_{2} \mathrm{O}$ (2:1), r.t., 24h; iii) MsCl, TEA, in DCM, r.t. 4-12 h; iv) [ $\left.{ }^{18} \mathrm{~F}\right]-K F, K 222, K_{2} \mathrm{HPO}_{4}, A C N, 90^{\circ} \mathrm{C}, 15 \mathrm{~min}$; v) $\mathrm{NaOH} 2 \mathrm{M}, 40^{\circ} \mathrm{C}, 10 \mathrm{~min}, \mathrm{HPLC}$ purification, radiochemical yield $25 \pm 5 \%(n=5)$ decay corrected.

Finally, automated $\left[{ }^{18} \mathrm{~F}\right]$-radiofluorination of 8 using the $\left[{ }^{18} \mathrm{~F}\right] \mathrm{KF}-\mathrm{K} 222 \mathrm{dry}$ complex in a modular reactor, followed by hydrolysis of methyl ester and acetate functions with $\mathrm{NaOH}$, afforded the tracer $\left[{ }^{18} \mathrm{~F}\right]-4 \mathrm{c}$ in $25 \pm 5 \%(n=5)$ decay corrected radiochemical yield, as a mixture of two epimers at the $\alpha$-amino acid carbon. The total radiosynthesis, purification and formulation time was about 90 minutes.

\subsection{Imaging results}

A pilot imaging experiment with $\left[{ }^{18} \mathrm{~F}\right]-\mathrm{LCATD}\left(\left[{ }^{18} \mathrm{~F}\right]-4 \mathrm{c}\right)$ in a wild type rat was performed for assessing biodistribution and clearance of the PET tracer. The radioactivity distribution (as coronal maximum intensity projections) at 1, 2, 5, 10, 20, 25 minutes after intravenous administration of $\left[{ }^{18} \mathrm{~F}\right]-$ LCATD in a representative control rat is shown in Fig. 8 (PET-CT). The radioactivity was primarily located in the liver with no obvious uptake in the kidneys or other organs in the abdominal region. The liver uptake and biliary excretion of radioactivity through the biliary duct was clearly visible after 1-2 minutes postinjection. At 20 minutes the radioactivity was localised mainly in the intestinal region while almost no signal was visible in the liver. 

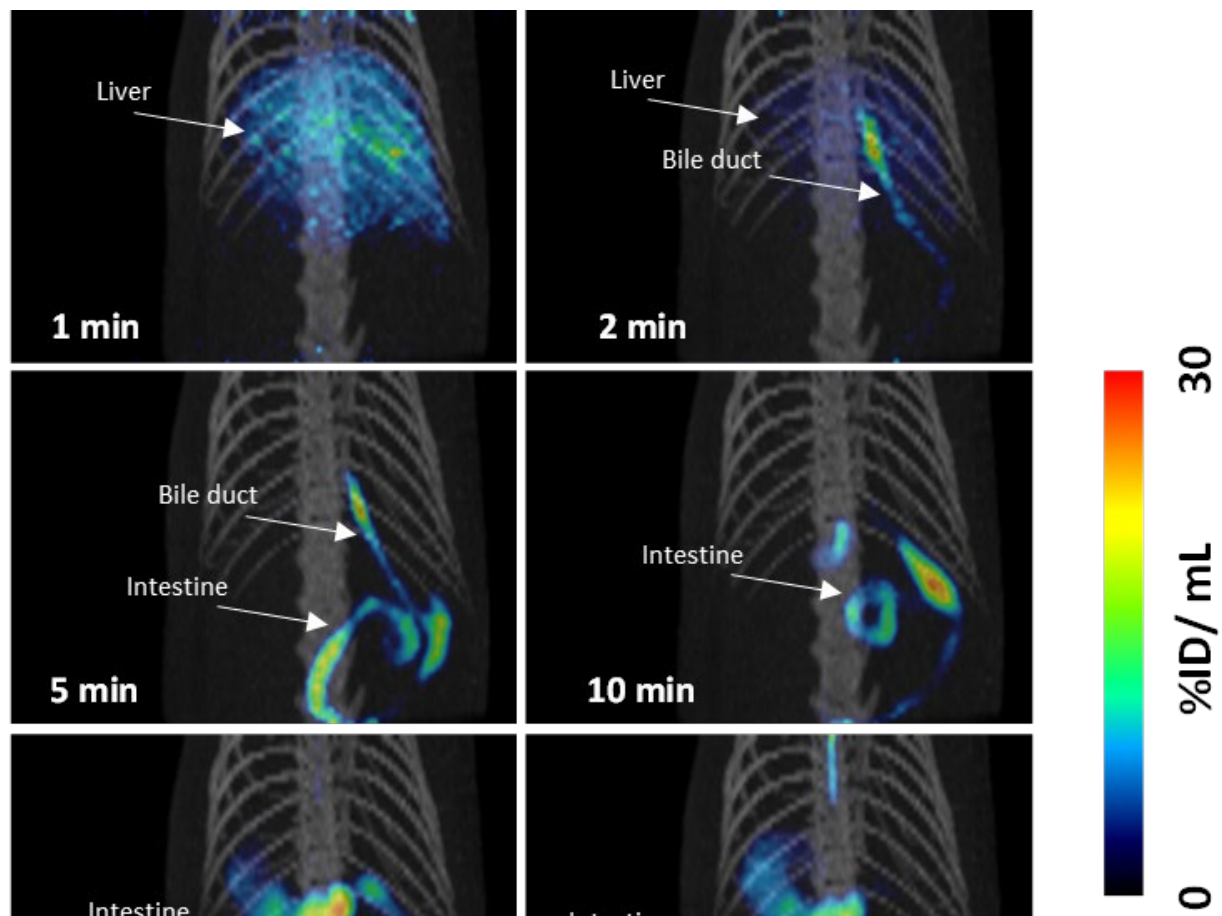

Figure 8. Images obtained for a representative control rat. At $1 \mathrm{~min}$ only the liver is visible. At $2 \mathrm{~min}$ the bile duct is clearly visible. From 5 to 25 minutes the intestine is visible because of the presence of the bile containing the radioactive tracer.

Time-activity curves (TAC) for the liver, blood and intestine are shown in Fig. 9. The activity in the blood, deduced from the activity of the region of interest (ROI) corresponding to the abdominal aorta, rapidly decreased after 15 seconds from the injection to less than $1 \%$ after $10 \mathrm{~min}$. The TAC in the liver increased linearly for the first 75 seconds post-injection, reached a peak corresponding to $12.4 \%$ of the injected dose at 165 seconds and then exponentially decreased to 1\% of the injected dose after 27 minutes. The TAC for the intestine ROI reached the maximum activity ( $29.5 \%$ of the injected dose) 8.75 minutes after the liver peak activity, at 11.5 minutes from the injection. After this time the activity measured in the intestine appeared to decrease, probably because of the bile flow to the lower intestine region, which was not entirely covered by the field of view of the PET scan.
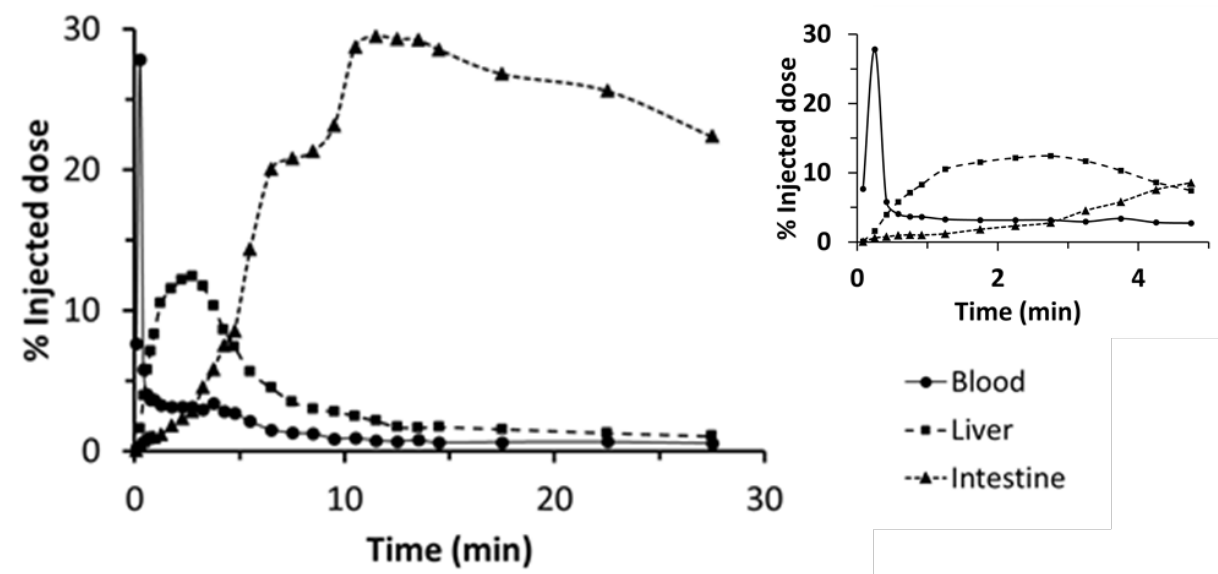

Figure 9. Time-activity curves for the three ROIs blood, liver and intestine after i.v. administration to SD rat $(n=1)$. Inset: time-activity curves from 0 to 5 minutes. 
Although a detailed analysis of the metabolic fate of $\left[{ }^{18} \mathrm{~F}\right]-4 \mathrm{c}$ is not yet available, the expected metabolism for compound $\mathbf{4} \mathbf{c}$ may be similar to that of lithocholic acid: in rats hydroxylation at the position 3, 6 and 7 may occur, as well as glucuronidation of the hydroxyl group in position $3,{ }^{24}$ while in humans, oxidation of the hydroxyl group to ketone and hydroxylation of positions 6 and 7 may be possible (3-ketocholanoic acid is the major in vitro human hepatic microsomal metabolite of lithocholic acid). ${ }^{25}$ The labelling position is however stable, as no uptake of $\left[{ }^{18} \mathrm{~F}\right]-$ fluoride in the bone tissue was observed in the PET-CT scan.

\section{DISCUSSION AND CONCLUSION}

In this study we synthesized three fluorinated derivatives of endogenous bile acids $4 a-c$ as candidate probes for imaging hepatic transporters activity (Fig. 10). The current project was focussed primarily on characterizing the in vitro transport of $4 \mathrm{a}-\mathrm{c}$ by OATP1B1/1B3 because of their well-understood role in clinical DDIs, ${ }^{2}$ but the possibility of 4 a-c being transported by other uptake transporters (for example, OATP2B1, OATP1A2, OAT2, OAT7) cannot be excluded. In addition to OATP1B1/1B3, bile salt transporters (NTCP/BSEP) were also studied because of the close structural similarity of $4 a-c$ to bile salts and hence the possibility of NTCP/BSEP being involved in their transport.

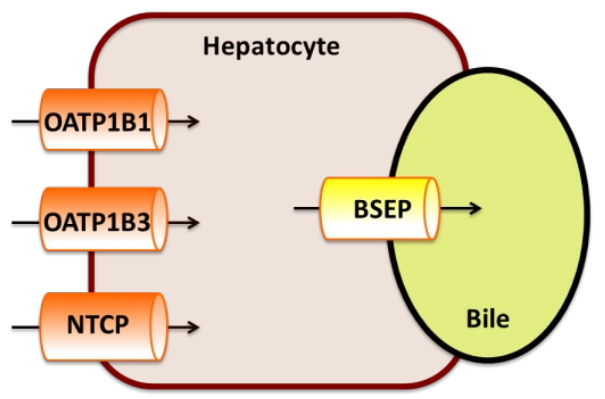

Fig. 10. Transporter proteins in the hepatocyte relevant to this study.

The three compounds $4 \mathrm{a}-\mathrm{c}$ share the same carbon-backbone but have different numbers of $\mathrm{OH}$ groups on the bile acid scaffold: this affects the lipophilicity of the compounds as well as their number of donor/acceptor hydrogen bonds (see Table 2). The bile acid derivatives 4a-c were readily prepared from commercial bile acids through a short synthetic route which also allowed the synthesis of tritium labeled compounds $\left[{ }^{3} \mathrm{H}\right]-\mathbf{4 a - c}$ used for in vitro assays.

The utility of PET in the imaging of hepatic transporters has been demonstrated in recent years by a number of publications in which several $\left[{ }^{11} \mathrm{C}\right]$-labeled PET tracers have been proposed. For example, $\left[{ }^{11} \mathrm{C}\right]$-cholylsarcosine has been successfully employed to image the biliary excretion in pigs, with potential applications in the study of pathophysiological conditions of the liver such as inherited cholestasis, acquired liver disease, acute hepatitis, primary biliary cirrhosis, post-transplantation liver dysfunction, and biliary obstruction. ${ }^{14,26}$ However, only $\left[{ }^{11} \mathrm{C}\right]$-labeled PET tracers have been developed so far to study hepatic membrane transporters, thus limiting the access to this valuable technology to PET centres with a cyclotron on site. ${ }^{27}$ In addition, the higher activity achievable for production run and the longer half-lives of $\left[{ }^{18} \mathrm{~F}\right]$-labeled tracers represent a clear advantage over $\left[{ }^{11} \mathrm{C}\right]$-tracers for both pre-clinical and clinical PET imaging. 
In order to identify and characterize the transporters involved in the hepatocyte uptake of the fluorinated bile acid derivatives $4 a-c$, in vitro assays were performed using the tritium labeled versions $\left[{ }^{3} \mathrm{H}\right]-4 a-c$. Because OATP1B1 is considered responsible for the hepatic uptake of several endogenous and exogenous compounds, we first tested our potential probes as substrates for this transporter. The assays demonstrated that compounds $4 \mathrm{a}-\mathrm{c}$ are substrates of OATP1B1, as the uptake ratios were higher than 1. However, the accumulation of $\left[{ }^{3} \mathrm{H}\right]-4 \mathrm{a}$ in HEK293-OATP1B1 cells reached a plateau after four minutes of incubations, while the uptake of $\left[{ }^{3} \mathrm{H}\right]-\mathbf{4 b}$ and $\left[{ }^{3} \mathrm{H}\right]-\mathbf{4 c}$ increased linearly with the time until the last time point (16 minutes) (Fig. 1 and 2). Values obtained for $K_{m}$ and $V_{\max }$ indicate that OATP1B1 mediated transport of $4 \mathbf{c}$ is comparable to that of several prototypical OATP1B1 probes (Table 1), therefore it was selected for studying the activity of OATP1B1 in vivo ${ }^{1}$ (Fig. 3 and Table 1). Inhibition experiments with rifamycin SV (Fig. 4) showed that the OATPB1 uptake of all the probe compounds was affected by the presence of the inhibitor drug in a dose-dependent manner. However, when $\left[{ }^{3} \mathrm{H}\right]-4 \mathrm{a}$ CATD was used as a substrate, the $\mathrm{IC}_{50}$ value could not be determined. Using $\left[{ }^{3} \mathrm{H}\right]-\mathbf{4} \mathbf{b}$ and $\left[{ }^{3} \mathrm{H}\right]-4 \mathrm{c}$ as substrates, the expected inhibition curves were obtained, with $\mathrm{IC}_{50}$ values $(0.13$ and 0.40 $\mu \mathrm{M}$ respectively) comparable with those obtained using the OATP1B1 reference substrate $\left[{ }^{3} \mathrm{H}\right]$ estradiol 17- $\beta$-glucuronide $\left(\mathrm{IC}_{50}=0.23 \pm 0.07 \mu \mathrm{M}\right)$ in the same cell system (Table 1$)^{6,{ }^{6,2}}$

OATP1B3 is closely related to OATP1B1 and it is known that bile acids, bilirubin and eicosanoids are among the endogenous substrates of both OATP1B3 and OATP1B1: ${ }^{11,28}$ For this reason compound $4 \mathbf{c}$ was tested in an OATP1B3 substrate assay (Fig. 5). Even though significant differences were found in the uptake rates between the transporter-expressing cells and the control cells, the uptake ratio $=2$ and the incomplete saturation of the transporter at $100 \mu \mathrm{M}$ suggest that $\mathbf{4 c}$ is a poor substrate of OATP1B3. In fact literature data about bile acids as substrates for OATP1B3 report $K_{m}$ of $85.3 \mu \mathrm{M}$ for cholic acid, and uptake ratios of 4.9 for prototypical substrates. ${ }^{29}$ The probe compound $4 \mathbf{c}$ showed significant linearly time dependent uptake by NTCP-CHO cells, and uptake ratios were 4-32 (Fig. 6). The NTCP-mediated transport of $4 c$ in HEK293 cells was saturable and the apparent $K_{m}$ and $V_{\max }$ were $49 \mu \mathrm{M}$ and $2035 \mathrm{pmol} / \mathrm{mg} / \mathrm{min}$, respectively (Fig. 7a). Reported value of $\mathrm{K}_{\mathrm{m}}$ for the prototypical substrate taurocholate in NTCP-CHO cells is $8.4 \pm 1.3 \mu \mathrm{M}^{30}$ which suggests that the introduction of a triazole-alkyl chain substituent on the $\alpha$-carbon of the glycine does not strongly affect the substrate recognition by NTCP, albeit it does reduce the affinity.

The bile acid derivative $\mathbf{4 c}$ was also tested as substrate of BSEP, which is the transporter involved in the efflux of bile salts from the hepatocyte and into the bile canaliculi (Fig. $7 \mathrm{~b}$ and 10). Although very few drugs are known to be substrates of BSEP, this transporter can be involved in drug induced liver injury caused by the accumulation of toxic bile acids in hepatocytes: the inhibition of BSEP by certain drugs was in fact correlated to the potential of cholestatic drug induced liver injury. ${ }^{31}$ In BSEP expressing membrane vesicles the derivative $\mathbf{4} \mathbf{c}$ exhibited concentration dependent ATP driven active transport suggesting that in vivo it might get excreted in bile. Our data indeed suggest that derivative $\mathbf{4 c}$ is a substrate of BSEP, which can play a role in the in vivo excretion of $\mathbf{4 c}$ from the hepatocyte into the bile.

Differences in uptake and efflux of compounds 4a-c could be analysed in light of their lipophilicity and number of donor/acceptor hydrogen bonds. Estimation of the lipophilicity of the endogenous bile acid conjugates and bile acid-triazole derivatives is provided in Table 2 . 


\begin{tabular}{|c|c|c|c|}
\hline Endogenous BA conjugate & Properties & BA-triazole derivatives & Properties \\
\hline (NO) & $\begin{array}{c}\text { CLogD }=0.31 \\
H B D=5 \\
H B A=7\end{array}$ & $4 a$ & $\begin{array}{c}C \log D=0.92 \\
H B D=5 \\
H B A=10\end{array}$ \\
\hline $\mathrm{CO}_{2} \mathrm{H}$ & $\begin{array}{c}\text { CLogD }=0.97 \\
H B D=4 \\
H B A=6\end{array}$ & $4 b$ & $\begin{array}{c}C \log D=1.56 \\
H B D=4 \\
H B A=9\end{array}$ \\
\hline $\mathrm{HN}_{\mathrm{HNO}}^{\mathrm{O}}$ & $\begin{array}{c}\text { CLogD }=1.66 \\
H B D=3 \\
H B A=5\end{array}$ & $4 c$ & $\begin{array}{c}C \log D=2.20 \\
H B D=3 \\
H B A=8\end{array}$ \\
\hline
\end{tabular}

Table 2. Estimation of the lipophilicity of the bile acid derivatives $4 a-c$ and comparison to that of endogenous bile acids. CLogD calculated with StarDrop. HBD = Hydrogen Bond Donor atoms. HBA = Hydrogen Bond Acceptor atoms.

Compared to the endogenous bile acid conjugates, the corresponding labelled derivatives 4a-c appear to be more lipophilic and the introduction of the triazole ring increases the number of hydrogen bond acceptor atoms by 3. Difference in physicochemical properties between inhibitors and non-inhibitors of OATPs suggests that lipophilicity is positively correlated with the potential for interaction with such transporters. ${ }^{32}$ A substrate pharmacophore for OATP1B1 has been published in 2005 (whose key pharmacophore features appear to be two hydrogen bond acceptors at either end of a large hydrophobic area) ${ }^{33}$ however, structural information of the binding site would be required to rationalize the structure-activity relationship for the synthesized bile acid derivatives, as all of them can easily fit in the proposed pharmacophore.

The PET tracer version $\left[{ }^{18} \mathrm{~F}\right]-\mathbf{4 c}$ was synthesized and purified in an automated module which allowed the production of multi-GBq amount of radiotracer in good purity and yields for a pilot imaging experiment. In order to preliminarily assess the biodistribution of $\left[{ }^{18} \mathrm{~F}\right]-4 \mathrm{c}$, in vivo imaging experiments were performed in a single wild type rat. Even though there is not a direct orthologue of human OATP1B1 in rats and murine OATP1B3 and NTCP transporters have shown different affinity for their substrates compared to human transporters, ${ }^{1}$ the rat model is widely accepted for preclinical experiments aimed to assess the involvement of hepatic transporters in the clearance of drugs and radiotracers. ${ }^{1,15}$ The in vivo biodistribution of $\left[{ }^{18} \mathrm{~F}\right]-\mathbf{4 c}$ was found to be liver-specific, as the tracer uptake was selective in the liver and then the tracer was excreted in the bile: no activity was detected in the kidneys or urinary bladder (Fig. 8 and Fig. 9). Based on the in vitro tests, the liver uptake and excretion of $\left[{ }^{18} \mathrm{~F}\right]-4 \mathrm{c}$ should be mostly due to the effect of membrane transporter OATP1B1 and NTCP. The poor passive permeability of $\mathbf{4 c}$, which is ionized at physiological $\mathrm{pH}$, and the exclusive and fast distribution in the liver support this hypothesis. As expected, after being accumulated into the liver, the tracer is excreted into the bile via the efflux transporter BSEP, even if we cannot exclude the contribution of other efflux transporters such as MATE1, BCRP, MRP2 and PgP. The probe compound 
$\mathbf{4 c}$ is therefore transported by three of the major clinically relevant transporters involved in drug-drug interactions and drug induced liver injury (OATP1B1, NTCP and BSEP). This suggests that $\left[{ }^{18} \mathrm{~F}\right]-\mathbf{4 c}$ is a promising PET tracer to study in vivo the potential for transporters-mediated hepatotoxicity of clinically used drugs and investigational drugs.

A full pre-clinical PET imaging study using $\left[{ }^{18} \mathrm{~F}\right]-\mathbf{4 c}$ is currently in progress and will be reported in due course.

\section{Experimental}

Bile acids, chemicals and solvents used in the synthesis, rifamycin SV, sodium fusidate, Dulbecco's modified essential media (DMEM), Hanks' balanced salt solution (HBSS) and triton X-100 were purchased from Sigma-Aldrich UK. UltimaGold and Monoscint 20 scintillation cocktails were obtained from PerkinElmer Life and Analytical Sciences UK. Phosphate-buffered saline (without $\mathrm{CaCl}_{2}$ and $\mathrm{MgCl}_{2}$ ), geneticin (G418), and L-glutamine were purchased from Invitrogen, UK. Heat inactivated foetal calf serum was procured from PAA Laboratories GmbH UK. BD Biocoat ${ }^{\mathrm{TM}}$ Poly-D-lysine 24multiwell plates were purchased from BD Biosciences (Oxford, UK). Costar 96-well round bottom polypropylene microplates (Corning Inc.) were obtained from ThermoFisher Scientific. Multiscreen HTS 96-well GF/B filter plates and TopCount adaptors were purchased from Millipore (UK) Ltd. (Watford, UK). BD Falconä HTS 96-well flat bottom, tissue culture treated microplates were supplied by BD Biosciences Discovery Labware (Bedford, MA USA). Unifilter350 microplate GF-C plates were supplied by VWR. TopSeal A adhesive sealing film were obtained from PerkinElmer Life and Analytical Sciences (USA). Pierce ${ }^{\circledast}$ BCA Protein Assay kit was purchased from ThermoFisher Scientific UK.

${ }^{1} \mathrm{H}(400.13 \mathrm{MHz}),{ }^{13} \mathrm{C}(100.58 \mathrm{MHz})$ and ${ }^{19} \mathrm{~F}(376.45 \mathrm{MHz})$ NMR spectra were recorded on a Bruker ADVANCE III spectrometer. ${ }^{1} \mathrm{H}$ NMR chemical shifts are reported relative to the solvent resonance $\left(\mathrm{CDCl}_{3} \delta=7.26, \mathrm{CD}_{3} \mathrm{OD} \delta=3.31\right) .{ }^{13} \mathrm{C}$ NMR spectra were recorded with complete proton decoupling, and the chemical shifts are reported relative to the solvent resonance $\left(\mathrm{CDCl}_{3} \delta=77.0, \mathrm{CD}_{3} \mathrm{OD} \delta=\right.$ 49.0). The following abbreviations are used to describe spin multiplicity: $s=$ singlet, $d=$ doublet, $d d=$ doublet-doublet, $\mathrm{dt}=$ doublet-triplet, $\mathrm{t}=$ triplet, $\mathrm{dt}=$ doublet-triplet, $\mathrm{q}=$ quartet, $\mathrm{m}=$ multiplet, $\mathrm{bs}=$ broad signal. All chemical shifts $(\delta)$ are expressed in parts per million and coupling constant $(J)$ are given in Hertz. MS experiments were performed on an Agilent Technologies 1200 Series HPLC system equipped with a DAD and a 6120 MS detector composed by an ESI ionization source and a Single Quadrupole mass selective detector. HRMS were performed at the National Mass Spectrometry Facility (Swansea, UK). All reactions were carried out in oven- or flame-dried glassware under nitrogen atmosphere, unless stated otherwise. All commercially available reagents were used as received. Reactions were magnetically stirred. Flash chromatography was performed on silica gel (60 A, particle size $0.040-0.062 \mathrm{~mm}$ ). Yields refer to chromatographically and spectroscopically pure compounds, unless stated otherwise. The radiotracer synthesis and purification was performed using a Eckert and Ziegler ModularLab system equipped with the HPLC module. The purified hot tracer and the cold reference were analysed using a Shimadzu Prominence HPLC system equipped with a PDA UV detector and HERM LB500 activity detector. Phenomenex Luna C18 column, $5 \mu \mathrm{m}$, $100 \AA$, $250 \times 4.6 \mathrm{~mm}(\mathrm{~L} \times \mathrm{ID})$ and Phenomenex Luna C18 column, $5 \mu \mathrm{m}, 100 \AA, 250 \times 10.0 \mathrm{~mm}$ ( $\mathrm{L} \times \mathrm{ID})$ were used as analytical and semipreparative HPLC columns respectively.

\subsection{General procedure for the synthesis of compounds $\mathbf{2 a - c}$}


To a mixture of bile acid (1.22 mmol) and HATU (465 mg, $1.33 \mathrm{mmol})$ in DMF (20 mL), DIPEA (1.2 mL. $4.00 \mathrm{mmol}$ ) was added dropwise, followed by propargyclycine methyl ester hydrochloride $(217 \mathrm{mg}$, $1.33 \mathrm{mmol})$. The reaction mixture was stirred at room temperature for $3 \mathrm{~h}$. Water $(50 \mathrm{~mL})$ was then added and $\mathrm{HCl} 2 \mathrm{M}$ was used to adjust the $\mathrm{pH}=2.5-3$. The mixture was extracted with EtOAc $(30 \mathrm{~mL})$ and the organic phase was then washed with a saturated solution of $\mathrm{NaHCO}_{3}(30 \mathrm{~mL})$ and brine $(10 \mathrm{~mL})$. The organic phase was then dried over $\mathrm{MgSO}_{4}$ and the solvents removed at reduced pressure. The crude was purified via FCC using DCM/MeOH (15:1) as a mobile phase.

5.1.1. Methyl 2-(( $\left.R^{*}\right)-4-((3 R, 5 S, 7 R, 8 R, 9 S, 10 S, 12 S, 13 R, 14 S, 17 R)-3,7,12-t r i h y d r o x y-10,13-$ dimethylhexadecahydro-1H-cyclopenta[a]phenanthren-17-yl)pentanamido)pent-4-ynoate (2a) White amorphous solid in $87 \%$ yield $(550 \mathrm{mg}) .{ }^{1} \mathrm{H}$ NMR $\left(400 \mathrm{MHz}, \mathrm{CDCl}_{3}\right) \delta: 0.66(\mathrm{~s}, 3 \mathrm{H}), 0.87(\mathrm{~s}, 3 \mathrm{H})$, 0.92-1.12 (m, 5H), 1.26-1-92 (m, 18H), $2.04(\mathrm{q}, J=2.6 \mathrm{~Hz}, 1 \mathrm{H}), 2.15-2.23(\mathrm{~m}, 3 \mathrm{H}), 2.29-2.36(\mathrm{~m}, 1 \mathrm{H})$, 2.74-2.75 (m, 2H), 3.05 (br s, 3H), 3.38-3.45 (m, 1H), $3.77(\mathrm{~s}, 3 \mathrm{H}), 3.82$, (br s, 1H), 3.95 (br s, $1 \mathrm{H})$, 4.71-4.76 (m, 1H), 6.54 (dd, J = 7.9, $2.8 \mathrm{~Hz}, 1 \mathrm{H}) .{ }^{13} \mathrm{C} \mathrm{NMR}\left(100 \mathrm{MHz}, \mathrm{CDCl}_{3}\right) \delta: 12.5,17.4,22.4,23.3$, 26.3, 27.6, 28.1, 30.4, 31.4, 33.0, 33.1, 34.7, 34.8, 35.3, 39.5, 39.6, 41.5, 41.6, 46.4, 46.7, 46.8, 50.5, $52.8,68.5,71.5,71.6,71.9,73.1,78.7,171.1,173.6 . \mathrm{MS}(E S I, m / z): \mathrm{C}_{30} \mathrm{H}_{47} \mathrm{NO}_{6}[\mathrm{M}+\mathrm{H}]^{+}$calc. 518.3 found 518.3

5.1.2. Methyl 2-(( $\left.R^{*}\right)-4-((3 R, 5 R, 8 R, 9 S, 10 S, 12 S, 13 R, 14 S, 17 R)-3,12-d i h y d r o x y-10,13-$ dimethylhexadecahydro-1H-cyclopenta[a]phenanthren-17-yl)pentanamido)pent-4-ynoate (2b) White amorphous solid, in $82 \%$ yield. ${ }^{1} \mathrm{H} N M R\left(400 \mathrm{MHz}, \mathrm{CDCl}_{3}\right) \delta: 0.64(\mathrm{~s}, 3 \mathrm{H}), 0.87(\mathrm{~s}, 3 \mathrm{H}), 0.95-$ $0.98(\mathrm{~m}, 4 \mathrm{H}), 1.01-1.115(\mathrm{~m}, 2 \mathrm{H}), 1.20-1.84(\mathrm{~m}, 22 \mathrm{H}), 2.01-2.03(\mathrm{~m}, 1 \mathrm{H}), 2.11-2.34(\mathrm{~m}, 4 \mathrm{H}), 2.72-2.74$ (m, 2H), 3.53-3.60 (m, 1H), $3.75(\mathrm{~s}, 1 \mathrm{H}), 3.95$ (br. s, $1 \mathrm{H}), 4.70-4.74(\mathrm{~m}, 1 \mathrm{H}), 6.41(\mathrm{~d}, J=7.9 \mathrm{~Hz}, 1 \mathrm{H})$. NMR $\left(100 \mathrm{MHz}, \mathrm{CDCl}_{3}\right) \delta: 12.7,17.4,22.4,23.1,23.7,26.2,27.2,27.5,28.6,60.4,31.4,33.2,33.3$, 33.6, 34.1, 35.2, 35.3, 36.0, 36.4, 42.1, 46.5, 47.1, 48.1, 50.5, 52.8, 71.6, 71.7, 73.1, 78.6, 171.0, 171.1, 173.4. MS (ESI, $m / z): \mathrm{C}_{30} \mathrm{H}_{47} \mathrm{NO}_{5}[\mathrm{M}+\mathrm{H}]^{+}$calc. 502.3 found 502.3

5.1.3. Methyl 2-((R*)-4-((3R,5R,8R,9S,10S,13R,14S,17R)-3-hydroxy-10,13-dimethylhexadecahydro-1Hcyclopenta[a]phenanthren-17-yl)pentanamido)pent-4-ynoate (2c)

White amorphous solid, in $92 \%$ yield. ${ }^{1} \mathrm{H}$ NMR $\left(400 \mathrm{MHz}, \mathrm{CDCl}_{3}\right) \delta: 0.62(\mathrm{~s}, 3 \mathrm{H}), 0.90-1.15(\mathrm{~m}, 13 \mathrm{H})$, 1.22-1.57 (m, 12H), 1.63-1.66 (m, 1H), 1.70-1.85 (m, 6H) 1.93-1.96 (m, 1H), $2.01(\mathrm{t}, J=2.5 \mathrm{~Hz}, 1 \mathrm{H})$, 2.10-2.18 $(\mathrm{m}, 1 \mathrm{H}), 2.27-2.34(\mathrm{~m}, 1 \mathrm{H}), 2.74-2.76(\mathrm{~m}, 1 \mathrm{H}), 3.56-3.64(\mathrm{~m}, 1 \mathrm{H}), 3.77(\mathrm{~s}, 3 \mathrm{H}), 4.71-4.76(\mathrm{~m}$, $1 \mathrm{H}), 6.28(\mathrm{~d}, J=7.7 \mathrm{~Hz}, 1 \mathrm{H}) .{ }^{13} \mathrm{C} \mathrm{NMR}\left(100 \mathrm{MHz}, \mathrm{CDCl}_{3}\right) \delta: 12.1,18.4,20.8,22.5,23.4,24.2,26.4$, 27.2, 28.3, 30.5, 31.5, 33.3, 33.4, 34.6, 35.4, 35.9, 36.5, 40.2, 42.1, 42.8, 50.4, 52.8, 56.0, 56.5, 71.5, 71.8, 78.5, 171.0, 173.3. MS (ESI, $m / z): \mathrm{C}_{30} \mathrm{H}_{47} \mathrm{NO}_{4}[\mathrm{M}+\mathrm{H}]^{+}$calc. 486.4 found 486.4

\subsection{General procedure for the synthesis of compounds 3a-c}

1-Bromo-4-fluorobutane (155 mg, $1 \mathrm{mmol}$ ) was dissolved in DMF $\left(0.5 \mathrm{~mL}\right.$ ) and $\mathrm{NaN}_{3}$ was added (98 $\mathrm{mg}, 1.5 \mathrm{mmol})$. The mixture was stirred overnight. $\mathrm{Et}_{2} \mathrm{O}(1 \mathrm{~mL})$ and $\mathrm{H}_{2} \mathrm{O}(1 \mathrm{~mL})$ were added and the organic layer was transferred to a suspension of alkyne $2(0.5 \mathrm{mmol})$ in $t \mathrm{BuOH} / \mathrm{H}_{2} \mathrm{O}(2: 1,3 \mathrm{~mL})$. $\mathrm{CuSO}_{4}(8 \mathrm{mg}, 0.05 \mathrm{mmol})$ and sodium ascorbate $(30 \mathrm{mg}, 0.15 \mathrm{mmol})$ were added and the reaction mixture was stirred for 48 hours at room temperature. Saturated $\mathrm{NH}_{4} \mathrm{Cl}(10 \mathrm{~mL})$ was added, the mixture was extracted with EtOAc $(3 \times 10 \mathrm{~mL})$ and the organic phase was dried over $\mathrm{MgSO}_{4}$, solvents were removed under reduced pressure and the crude product was purified by FCC (DCM/MeOH gradient from 15:1 to $10: 1$ ). 
5.2.1 methyl 3-(1-(4-fluorobutyl)-1H-1,2,3-triazol-4-yl)-2-(( $\left.R^{*}\right)-4-$

$((3 R, 5 S, 7 R, 8 R, 9 S, 10 S, 12 S, 13 R, 14 S, 17 R)-3,7,12$-trihydroxy-10,13-dimethylhexadecahydro-1Hcyclopenta[a]phenanthren-17-yl)pentanamido)propanoate (3a)

Prepared from alkyne 2a, white foam, $89 \%$ yield. ${ }^{1} \mathrm{H}$ NMR $\left(400 \mathrm{MHz}, \mathrm{CDCl}_{3}\right) \delta: 0.67(\mathrm{~s}, 3 \mathrm{H}), 0.88(\mathrm{~s}$, $3 \mathrm{H}), 0.94-1.00(\mathrm{~m}, 4 \mathrm{H}), 1.03-1.15(\mathrm{~m}, 1 \mathrm{H}), 1.23-1.31(\mathrm{~m}, 1 \mathrm{H}), 1.38-1.44(\mathrm{~m}, 4 \mathrm{H}), 1.49-1.95(\mathrm{~m}, 16 \mathrm{H})$, 2.00-2.08 (m, 2H), 2.13-2.31 (m, 6H), 3.18-3.25 (m, 2H), 3.42-3.47 (m, 1H), $3.71(\mathrm{~s}, 1 \mathrm{H}), 3.84(\mathrm{br} \mathrm{s}$, $1 \mathrm{H}), 3.96(\mathrm{br} \mathrm{s}, 1 \mathrm{H}), 4.36-4.42(\mathrm{~m}, 3 \mathrm{H}), 4.52(\mathrm{t}, J=5.7 \mathrm{~Hz}, 1 \mathrm{H}), 4.87-4.93(\mathrm{~m}, 1 \mathrm{H}), 6.80-6.85(\mathrm{~m}, 1 \mathrm{H})$, $7.40(\mathrm{~s}, 1 \mathrm{H}) .{ }^{19} \mathrm{~F}$ NMR $\left(376.45 \mathrm{MHz}, \mathrm{CDCl}_{3}\right) \delta:-218.94,-218.91 .{ }^{13} \mathrm{C} \mathrm{NMR}\left(100 \mathrm{MHz}, \mathrm{CDCl}_{3}\right) \delta: 12.5$, 17.4, 22.5, 23.2, 26.5, 27.2 (d, $J=20.1 \mathrm{~Hz}$ ), 27.5, 27.9, 28.2, 29.7, 30.5, 31.3, 33.0, 34.6, 34.7, 35.3, 39.6, 39.7, 41.5, 41.9, 46.5, 46.6, 49.8, 51.6, 52.5, 54.6, 68.4, 71.9, 73.0, 83.3 (d, $J=165.5 \mathrm{~Hz}$ ), 122.1, 143.1, 171.8, 173.8. MS (ESI, $m / z): \mathrm{C}_{34} \mathrm{H}_{55} \mathrm{FN}_{4} \mathrm{O}_{6}[\mathrm{M}+\mathrm{H}]^{+}$calc. 635.4 found 635.4

5.2.2 Methyl 2-((R*)-4-((3R,5R,8R,9S,10S,12S,13R,14S,17R)-3,12-dihydroxy-10,13-

dimethylhexadecahydro-1H-cyclopenta[a]phenanthren-17-yl)pentanamido)-3-(1-(4-fluorobutyl)-1H1,2,3-triazol-4-yl)propanoate (3b)

Prepared from alkyne $\mathbf{2 b}$, white foam, $85 \%$ yield. ${ }^{1} \mathrm{H}$ NMR $\left(400 \mathrm{MHz}, \mathrm{CDCl}_{3}\right) \delta: 0.67(\mathrm{~s}, 3 \mathrm{H}), 0.88(\mathrm{~s}$, $3 \mathrm{H}), 0.94-1.00(\mathrm{~m}, 4 \mathrm{H}), 1.03-1.15(\mathrm{~m}, 1 \mathrm{H}), 1.23-1.31(\mathrm{~m}, 1 \mathrm{H}), 1.38-1.44(\mathrm{~m}, 4 \mathrm{H}), 1.49-1.95(\mathrm{~m}, 16 \mathrm{H})$, 2.00-2.08 (m, 2H), 2.13-2.31 (m, 6H), 3.18-3.25 (m, 2H), 3.42-3.47 (m, 1H), $3.71(\mathrm{~s}, 1 \mathrm{H}), 3.84(\mathrm{br} \mathrm{s}$, $1 \mathrm{H}), 3.96(\mathrm{br} \mathrm{s}, 1 \mathrm{H}), 4.36-4.42(\mathrm{~m}, 3 \mathrm{H}), 4.52(\mathrm{t}, J=5.7 \mathrm{~Hz}, 1 \mathrm{H}), 4.87-4.93(\mathrm{~m}, 1 \mathrm{H}), 6.80-6.85(\mathrm{~m}, 1 \mathrm{H})$, 7.40 (s, $1 \mathrm{H}) .{ }^{19} \mathrm{~F}$ NMR $\left(376.45 \mathrm{MHz}, \mathrm{CDCl}_{3}\right) \delta:-218.94,-218.91 .{ }^{13} \mathrm{C} \mathrm{NMR}\left(100 \mathrm{MHz}, \mathrm{CDCl}_{3}\right) \delta: 12.8$, 17.4, 23.2, 23.7, 26.1, 26.5, 27.1, 27.3, 27.4, 27.5, 27.8, 27.9, 29.7, 30.5, 31.4, 33.2, 33.6, 34.1, 35.2, $35.3,36.0,36.5,42.1,46.5,47.0,47.1,49.8,51.6,52.5,71.7,73.1,82.4,84.0,122.0,143.1,171.7$, $171.8,173.6 \mathrm{MS}(E S I, m / z): \mathrm{C}_{34} \mathrm{H}_{55} \mathrm{FN}_{4} \mathrm{O}_{5}[\mathrm{M}+\mathrm{H}]^{+}$calc. 619.4 found 619.4

5.2.3 Methyl 3-(1-(4-fluorobutyl)-1H-1,2,3-triazol-4-yl)-2-((R*)-4-((3R,5R,8R,9S, 10S, 13R, 14S, 17R)-3hydroxy-10,13-dimethylhexadecahydro-1H-cyclopenta[a]phenanthren-17-

yl)pentanamido)propanoate (3c)

Prepared from alkyne $2 \mathrm{c}$, white foam, $86 \%$ yield. ${ }^{1} \mathrm{H} \mathrm{NMR}\left(400 \mathrm{MHz}, \mathrm{CDCl}_{3}\right) \delta: 0.60(\mathrm{~s}, 3 \mathrm{H}), 0.87-0.89$ $(\mathrm{m}, 6 \mathrm{H}), 0.94-1.40(\mathrm{~m}, 18 \mathrm{H}), 1.46-1.54(\mathrm{~m}, 2 \mathrm{H}), 1.62-2.12(\mathrm{~m}, 13 \mathrm{H}), 2.20-2.29(\mathrm{~m}, 1 \mathrm{H}), 3.15-3.26(\mathrm{~m}$, $2 \mathrm{H}), 5.55-3.63(\mathrm{~m}, 1 \mathrm{H}), 3.68(\mathrm{~s}, 3 \mathrm{H}), 4.34-4.40(\mathrm{~m}, 3 \mathrm{H}), 4.50(\mathrm{t}, J=5.6 \mathrm{~Hz}, 1 \mathrm{H}), 4.85-4.90(\mathrm{~m}, 1 \mathrm{H}), 6.64$ $(\mathrm{d}, J=7.7 \mathrm{~Hz}, 1 \mathrm{H}), 7.34(\mathrm{~s}, 1 \mathrm{H}) .{ }^{19} \mathrm{~F}$ NMR $\left(376.45 \mathrm{MHz}, \mathrm{CDCl}_{3}\right) \delta:-219.00,-219.01 .{ }^{13} \mathrm{C} \mathrm{NMR}(100 \mathrm{MHz}$, $\left.\mathrm{CDCl}_{3}\right) \delta: 12.0,18.3,20.8,23.4,24.2,26.4,26.5,27.1,27.2,27.3,27.8,28.2,30.5,31.5,33.4,34.6$, 35.4, 35.8, 36.5, 40.1, 40.4, 42.1, 42.7, 49.7, 51.5, 52.5, 56.0, 56.4, 71.7, 82.4, 84.0, 122.0, 143.1, 171.7, 173.6. $\mathrm{MS}(E S I, m / z): \mathrm{C}_{34} \mathrm{H}_{55} \mathrm{FN}_{4} \mathrm{O}_{4}[\mathrm{M}+\mathrm{H}]^{+}$calc. 603.4 found 603.4

\subsection{General procedure for the synthesis of compounds $4 a-c$}

The methyl ester 3 (100 mg, $0.157 \mathrm{mmol})$ was dissolved in $\mathrm{MeOH}(2 \mathrm{~mL})$ and $\mathrm{KOH} 2 \mathrm{M}(1 \mathrm{~mL})$ was added. The mixture was stirred at room temperature for 3 hours, the volatile components were removed, $\mathrm{H}_{2} \mathrm{O}(2 \mathrm{~mL})$ was added and concentrated $\mathrm{HCl}$ was added dropwise to precipitate the acid 4 .

5.3.1. 3-(1-(4-fluorobutyl)-1H-1,2,3-triazol-4-yl)-2-((R*)-4-((3R,5S, 7R, 8R,9S, 10S, 12S,13R,14S, 17R)3,7,12-trihydroxy-10,13-dimethylhexadecahydro-1H-cyclopenta[a]phenanthren-17yl)pentanamido)propanoic acid (4a), CATD

Prepared from methyl ester $3 a, 96 \mathrm{mg}, 98 \%$ yield as a white solid. ${ }^{1} \mathrm{H} \mathrm{NMR}\left(400 \mathrm{MHz}, \mathrm{CD}_{3} \mathrm{OD}\right) \delta: 0.71$ $(\mathrm{s}, 3 \mathrm{H}), 0.93(\mathrm{~s}, 3 \mathrm{H}), 0.96-1.16(\mathrm{~m}, 5 \mathrm{H}), 1.28-1.49(\mathrm{~m}, 7 \mathrm{H}), 1.52-1.89(\mathrm{~m}, 12 \mathrm{H}), 1.94-2.06(\mathrm{~m}, 6 \mathrm{H}), 2.10-$ $2.019(\mathrm{~m}, 1 \mathrm{H}), 2.23-2.34(\mathrm{~m}, 3 \mathrm{H}), 3.09-3.15(\mathrm{~m}, 1 \mathrm{H}), 3.28-3.29(\mathrm{~m}, 1 \mathrm{H}), 3.35-3.42(\mathrm{~m}, 1 \mathrm{H}), 3.80-3.82$ $(\mathrm{m}, 1 \mathrm{H}), 3.96(\mathrm{br} \mathrm{s}, 1 \mathrm{H}), 4.39-4.45(\mathrm{~m}, 3 \mathrm{H}), 4.52(\mathrm{t}, J=5.8 \mathrm{~Hz}, 1 \mathrm{H}), 4.71-4.75(\mathrm{~m}, 1 \mathrm{H}), 7.79(\mathrm{~s}, 1 \mathrm{H}) .{ }^{19} \mathrm{~F}$ 
NMR (376.45 MHz, CD 3 OD) $\left.\delta:-220.53,-220.52 .{ }^{13} \mathrm{C} \mathrm{NMR} \mathrm{(100} \mathrm{MHz,} \mathrm{CD}_{3} \mathrm{OD}\right) \delta: 11.6,16.3,21.8,22.8$, 26.1, 26.5, 27.0 (d, $J=20.1 \mathrm{~Hz}$ ), 27.3, 27.4, 28.2, 29.8, 31.7, 32.4, 34.5, 35.1, 35.4, 39.1, 39.6, 41.6, 41.8, 46.1, 46.7, 49.5, 52.0, 60.2, 67.7, 71.5, 72.7, 82.8 (d, $J=164.3 \mathrm{~Hz}$ ), 122.9, 143.4 (br signal), 172.7, 175.3. MS (ESI, $m / z): \mathrm{C}_{33} \mathrm{H}_{53} \mathrm{FN}_{4} \mathrm{O}_{6}[\mathrm{M}+\mathrm{H}]^{+}$calc. 621.4 found 621.4 5.3.2.

(( $\left.R^{*}\right)-4-((3 R, 5 R, 8 R, 9 S, 10 S, 12 S, 13 R, 14 S, 17 R)-3,12-d i h y d r o x y-10,13-d i m e t h y / h e x a d e c a h y d r o-1 H$ cyclopenta[a]phenanthren-17-yl)pentanamido)-3-(1-(4-fluorobutyl)-1H-1,2,3-triazol-4-yl)propanoic acid (4b)

Prepared from the ester $3 \mathrm{~b}$, white solid, $98 \%$ yield. ${ }^{1} \mathrm{H}$ NMR $\left(400 \mathrm{MHz}, \mathrm{CDCl}_{3}\right) \delta: 0.66(\mathrm{~s}, 3 \mathrm{H}), 0.90(\mathrm{~s}$, $3 \mathrm{H}), 0.94(\mathrm{dd}, \mathrm{J}=15.3,6.0 \mathrm{~Hz}, 2 \mathrm{H}), 1.02-1.12(\mathrm{~m}, 2 \mathrm{H}), 1.20-1.85(\mathrm{~m}, 25 \mathrm{H}), 2.00-2.07(\mathrm{~m}, 2 \mathrm{H}), 2.11-2.19$ $(\mathrm{M}, 1 \mathrm{H}), 2.23-2.29(\mathrm{M}, 1 \mathrm{H}), 3.29(\mathrm{~d}, \mathrm{~J}=6.0 \mathrm{~Hz}, 2 \mathrm{H}), 3.57-3.64(\mathrm{~m}, 1 \mathrm{H}), 3.99(\mathrm{~d}, \mathrm{~J}=2.4 \mathrm{~Hz}, 1 \mathrm{H}), 4.37-$ $4.41(\mathrm{~m}, 3 \mathrm{H}), 4.52(\mathrm{t}, \mathrm{J}=5.7 \mathrm{~Hz}, 1 \mathrm{H}), 4.79-4.81(\mathrm{~m}, 1 \mathrm{H}), 7.23(\mathrm{~d}, \mathrm{~J}=8 . \mathrm{Hz}, 1 \mathrm{H}), 5.54(\mathrm{~s}, 1 \mathrm{H}) .{ }^{19} \mathrm{~F} \mathrm{NMR}$ $\left(376.45 \mathrm{MHz}, \mathrm{CDCl}_{3}\right) \delta:-218.69,-218.72 .{ }^{13} \mathrm{C} \mathrm{NMR}\left(100 \mathrm{MHz}, \mathrm{CDCl}_{3}\right) \delta: 12.7,17.3,17.4,23.1,23.7$, 26.2, 26.4, 26.5, 27.1, 27.3, 27.6, 28.4, 29.7, 30.2, 31.4, 33.5, 34.2, 35.3, 36.0, 36.1, 42.1, 46.5, 46.6, 48.1, 50.0, 52.1, 71.7, 73.4, 82.4, 84.1, 122.8, 143.3, 143.5, 173.2, 174.8, 174.9. MS (ESI, $\mathrm{m} / \mathrm{z}$ ): $\mathrm{C}_{33} \mathrm{H}_{53} \mathrm{FN}_{4} \mathrm{O}_{5}[\mathrm{M}+\mathrm{H}]^{+}$calc. 605.4 found 605.4

5.3.3 3-(1-(4-fluorobutyl)-1H-1,2,3-triazol-4-yl)-2-((R*)-4-((3R,5R,8R,9S, 10S,13R,14S, 17R)-3-hydroxy10,13-dimethylhexadecahydro-1H-cyclopenta[a]phenanthren-17-yl)pentanamido)propanoic acid (4c), LCATD

Prepared from the ester $3 \mathrm{c}$, white solid, $98 \%$ yield. ${ }^{1} \mathrm{H}$ NMR $\left(400 \mathrm{MHz}, \mathrm{CDCl}_{3}\right) \delta: 0.62(\mathrm{~s}, 3 \mathrm{H}), 0.87-2.14$ $(\mathrm{m}, 37 \mathrm{H}), 2.25-2.31(\mathrm{~m}, 1 \mathrm{H}), 3.32-3.37(\mathrm{~m}, 2 \mathrm{H}), 3.60-3.65(\mathrm{~m}, 2 \mathrm{H}), 4.38-4.42(\mathrm{~m}, 3 \mathrm{H}), 4.50-4.53(\mathrm{~m}$, 1H), 4.72-4.73 (m, 1H), 6.87 (br. s, $1 \mathrm{H}) 7.48(\mathrm{~s}, 1 \mathrm{H}) .{ }^{19} \mathrm{~F} \mathrm{NMR}\left(376.45 \mathrm{MHz}, \mathrm{CDCl}_{3}\right) \delta:-219.27 .{ }^{13} \mathrm{C} \mathrm{NMR}$ (100 MHz, CD $\left.{ }_{3} \mathrm{OD}\right) \delta: 11.2,17.5,20.1,22.6,23.9,26.1,26.2,26.3,27.0,27.2,27.5,27.9,29.8,31.7$, 32.5, 34.3, 35.1, 35.4, 35.8, 35.9, 40.1, 40.5, 42.2, 42.5, 49.5, 56.0, 56.5, 71.0, 82.0, 83.7, 122.9, 143.5, $175.1 \mathrm{HRMS}(E S I, m / z): \mathrm{C}_{33} \mathrm{H}_{53} \mathrm{FN}_{4} \mathrm{O}_{4}[\mathrm{M}+\mathrm{H}]^{+}$calc. 589.4051 found 589.4062

\subsection{General procedure for the synthesis of compounds $\mathbf{5 a - c}$}

Alkyne $2(0.5 \mathrm{mmol})$ was dissolved in THF $(2.5 \mathrm{~mL})$ and treated with $\mathrm{N}$-iodomorpholine-hydrogen iodide ( $260 \mathrm{mg}, 0.75 \mathrm{mmol}$ ) followed by Cul $(10 \mathrm{mg}, 0.05 \mathrm{mmol})$. Sample was stirred for 2 hours and after this time the suspension was poured onto a pad of neutral alumina ( $\sim 10 \mathrm{~mL})$ and the solution was collected under vacuum. The pad was then washed 3 times with a solution of methanol in DCM $(5 \%, 10 \mathrm{~mL})$. The volatile were evaporated to give a yellow wax. 1-fluoro-4-azidobutane (approximately $0.75 \mathrm{mmol}$, unpurified) THF ( $2.5 \mathrm{~mL}$ ), Cul and ( $5 \mathrm{mg}, 0.025 \mathrm{mmol})$ TEA (140 $\mu \mathrm{L}, 1.00$ $\mathrm{mmol}$ ) were added. The mixture was stirred at room temperature for 24 hours. After this time the reaction was quenched by adding $1 \mathrm{~mL}$ of $10 \% \mathrm{NH}_{4} \mathrm{OH}$ solution. The crude mixture was extracted with ethyl acetate $(3 \times 10 \mathrm{~mL})$, washed with brine, dried over $\mathrm{MgSO}_{4}$ and the volatile components were removed by evaporation. The crude was purified by FCC (DCM/MeOH gradient from 15:1 to 10:1)).

5.4.1 Methyl 3-(1-(4-fluorobutyl)-5-iodo-1H-1,2,3-triazol-4-yl)-2-((R*)-4-

((3R,5S, 7R, 8R,9S,10S, 12S,13R,14S,17R)-3,7,12-trihydroxy-10,13-dimethylhexadecahydro-1Hcyclopenta[a]phenanthren-17-yl)pentanamido)propanoate (5a)

Prepared from alkyne $2 \mathrm{a}, 300 \mathrm{mg}, 80 \%$ yield, pale yellow foam. ${ }^{1} \mathrm{H} \mathrm{NMR}\left(400 \mathrm{MHz}, \mathrm{CDCl}_{3}\right) \delta: 0.66$ (s, $3 \mathrm{H}), 0.87(\mathrm{~s}, 3 \mathrm{H}), 0.95-0.97(\mathrm{~m}, 4 \mathrm{H}), 1.05-1.14(\mathrm{~m}, 1 \mathrm{H}), 1.23-1.27(\mathrm{~m}, 1 \mathrm{H}), 1.38-1.44(\mathrm{~m}, 4 \mathrm{H}), 1.47-$ 
$1.59(\mathrm{~m}, 4 \mathrm{H}), 1.65-1.79(\mathrm{~m}, 8 \mathrm{H}), 1.85-1.95(\mathrm{~m}, 3 \mathrm{H}), 2.00-2.08(\mathrm{~m}, 2 \mathrm{H}), 2.12-2.32(\mathrm{~m}, 6 \mathrm{H}), 3.12-3.23$ $(\mathrm{m}, 2 \mathrm{H}), 3.39-3.47(\mathrm{~m}, 1 \mathrm{H}), 3.72(\mathrm{~s}, 3 \mathrm{H}), 3.83(\mathrm{br} \mathrm{s}, 1 \mathrm{H}), 3.95(\mathrm{br}, 1 \mathrm{H}), 3.38-3.43(\mathrm{~m}, 3 \mathrm{H}), 4.53(\mathrm{t}, \mathrm{J}=5.7$ $\mathrm{Hz}, 1 \mathrm{H}), 4.90-4.95(\mathrm{~m}, 1 \mathrm{H}), 6.76-6.81(\mathrm{~m}, 1 \mathrm{H}) .{ }^{19} \mathrm{~F} \mathrm{NMR}\left(376.45 \mathrm{MHz}, \mathrm{CDCl}_{3}\right) \delta:-219.12,-219.14 .{ }^{13} \mathrm{C}$ NMR $\left(100 \mathrm{MHz}_{\mathrm{CDCl}}\right.$ ) $\delta: 12.5,17.4,22.5,23.2,25.9,26.0,26.5,27.2(\mathrm{~d}, J=20.0 \mathrm{~Hz}), 27.5,28.1$, 28.2, 30.5, 31.3, 33.1, 33.2, 34.6, 34.7, 35.3, 39.6, 39.7, 41.5, 41.8, 46.5, 46.7, 46.8, 50.4, 51.1, 52.6, $68.4,71.9,73.0,77.2,79.8,83.1$ (d, $J=165.8 \mathrm{~Hz}), 147.5,171.5,173.6,173.7 . \mathrm{MS}(E S I, m / z):$

$\mathrm{C}_{34} \mathrm{H}_{55} \mathrm{FNN}_{4} \mathrm{O}_{6}$ calc. 761.3 , found 761.3

5.4.2. Methyl 2-((R*)-4- $((3 R, 5 R, 8 R, 9 S, 10 S, 12 S, 13 R, 14 S, 17 R)-3,12-d i h y d r o x y-10,13-$ dimethylhexadecahydro-1H-cyclopenta[a]phenanthren-17-yl)pentanamido)-3-(1-(4-fluorobutyl)-5iodo-1H-1,2,3-triazol-4-yl)propanoate (5b)

Prepared from alkyne $\mathbf{2 b}, 297 \mathrm{mg}, 80 \%$ yield, pale yellow foam. $\left.{ }^{1} \mathrm{H} \mathrm{NMR} \mathrm{(400} \mathrm{MHz,} \mathrm{CDCl}_{3}\right) \delta: 0.66$ (s, $3 \mathrm{H}), 0.90(\mathrm{~s}, 3 \mathrm{H}), 0.94-1.87(\mathrm{~m}, \mathrm{XH}), 2.02-2.09(\mathrm{~m}, 2 \mathrm{H}), 2.12-2.18(\mathrm{~m}, 1 \mathrm{H}), 2.25-2.32(\mathrm{~m}, 1 \mathrm{H}), 3.12-$ $3.24(\mathrm{~m}, 2 \mathrm{H}), 3.56-3.64(\mathrm{~m}, 1 \mathrm{H}), 3.73(\mathrm{~s}, 3 \mathrm{H}), 3.97(\mathrm{br} . \mathrm{s}, 1 \mathrm{H}), 4.39-4.43(\mathrm{~m}, 3 \mathrm{H}), 4.53(\mathrm{t}, J=5.8 \mathrm{~Hz}, 1 \mathrm{H})$, 4.92-4.96 (m, 1H), $6.66(\mathrm{~d}, J=8.0 \mathrm{~Hz}, 1 \mathrm{H}) .{ }^{19} \mathrm{~F} \mathrm{NMR}\left(376.45 \mathrm{MHz}, \mathrm{CDCl}_{3}\right) \delta:-219.21 .{ }^{13} \mathrm{C} \mathrm{NMR}(100$ $\left.\mathrm{MHz}, \mathrm{CDCl}_{3}\right) \delta: 12.8,17.5,23.2,23.7,25.9,26.1,27.1,27.3,27.4,27.5,28.1,28.6,30.5,31.3,33.3$, 33.7, 34.1, 35.1, 35.2, 36.0, 36.5, 42.1, 46.5, 47.2, 48.2, 50.4, 51.0, 52.6, 71.8, 73.1, 77.2, 79.6, 82.3, 83.9, 147.5, 171.4, 171.5, 173.4. MS (ESI, $m / z): \mathrm{C}_{34} \mathrm{H}_{55} \mathrm{FIN}_{4} \mathrm{O}_{5}[\mathrm{M}+\mathrm{H}]^{+}$calc. 745.3 found 745.3.

5.4.3. Methyl 3-(1-(4-fluorobutyl)-5-iodo-1H-1,2,3-triazol-4-yl)-2-((R*)-4-

$((3 R, 5 R, 8 R, 9 S, 10 S, 13 R, 14 S, 17 R)-3$-hydroxy-10,13-dimethylhexadecahydro-1H-

cyclopenta[a]phenanthren-17-yl)pentanamido)propanoate (5c)

Prepared from alkyne 2c, $290 \mathrm{mg}, 80 \%$ yield, pale yellow foam. ${ }^{1} \mathrm{H} \mathrm{NMR}\left(400 \mathrm{MHz}, \mathrm{CDCl}_{3}\right) \delta: 0.66$ (s, $3 \mathrm{H}), 0.88-0.90(\mathrm{~m}, 6 \mathrm{H}), 0.95-1.41(\mathrm{~m}, 18 \mathrm{H}), 1.48-1.58(\mathrm{~m}, 4 \mathrm{H}), 1.64-1.86(\mathrm{~m}, 8 \mathrm{H}), 1.92-1.95(\mathrm{~m}, 1 \mathrm{H})$, 2.01-2.15 (m, 3H), 2.24-2.31 (m, 1H), 3.12-3.24 (m, 2H), 3.56-3.65 (m,1H), 3.72 (s, 3H), 4.39-4.43 (m, $3 \mathrm{H}), 4.53(\mathrm{t}, J=5.7 \mathrm{~Hz}, 1 \mathrm{H}), 4.91-4.97(\mathrm{~m}, 1 \mathrm{H}), 6.61(\mathrm{~d}, J=7.8 \mathrm{~Hz}, 1 \mathrm{H}) .{ }^{19} \mathrm{~F} \mathrm{NMR}\left(376.45 \mathrm{MHz}, \mathrm{CDCl}_{3}\right) \delta$ : -219.27. ${ }^{13} \mathrm{C} \mathrm{NMR}\left(100 \mathrm{MHz}, \mathrm{CDCl}_{3}\right) \delta: 12.1,18.3,20.8,23.4,24.2,25.9,26.4,27.1,27.2,27.3,28.1$, 28.2, 30.6, 31.4, 33.4, 34.6, 35.4, 35.4, 35.5, 35.9, 36.5, 40.2, 40.4, 42.1, 42.7, 50.4, 50.0, 52.6, 56.0, $56.5,71.9,77.2,79.6,82.3,83.9,147.5,162.5,171.5,173.4 . \mathrm{MS}(E S I, m / z): \mathrm{C}_{34} \mathrm{H}_{55} \mathrm{FIN}_{4} \mathrm{O}_{4}[\mathrm{M}+\mathrm{H}]^{+}$calc. 729.3 found 729.3 .

\subsection{Tritium labelling}

Labelling with tritium was performed according to the previously reported procedure. ${ }^{21}$

\subsection{Synthesis of precursors for radiofluorination}

5.6.1 Methyl 2-((R*)-4-((3R,5R,8R,9S,10S,13R,14S,17R)-3-acetoxy-10,13-dimethylhexadecahydro-1Hcyclopenta[a]phenanthren-17-yl)pentanamido)pent-4-ynoate (6)

To a solution of alkyne $2 \mathrm{c}(200 \mathrm{mg}, 0.41 \mathrm{mmol})$ in anhydrous pyridine $(1 \mathrm{~mL})$, acetic anhydride $(78 \mu \mathrm{L}$, $0.82 \mathrm{mmol}$ ) was added. The mixture was stirred for 3 hours at room temperature. The solvent was removed under reduced pressure and the crude was dissolved in AcOEt and washed with a saturated solution of $\mathrm{NaHCO}_{3}$. The organic phase was dried over $\mathrm{MgSO}_{4}$, the solvent was removed and the product purified via FCC (Hex/AcOEt 8:2) to give the title compound as a white foam in quantitative yield (215 $\mathrm{mg})$.

${ }^{1} \mathrm{H} \mathrm{NMR}\left(400 \mathrm{MHz}, \mathrm{CDCl}_{3}\right) \delta$ : $0.64(\mathrm{~s}, 3 \mathrm{H}), 0.92-0.94(\mathrm{~m}, 6 \mathrm{H}), 1.02-1.45(\mathrm{~m}, 17 \mathrm{H}), 1.52-1.57(\mathrm{~m}, 2 \mathrm{H})$, 1.67-1.69 $(\mathrm{m}, 1 \mathrm{H}), 1.78-1.88(\mathrm{~m}, 5 \mathrm{H}), 1.95(\mathrm{~d}, \mathrm{~J}=11.7 \mathrm{~Hz}, 1 \mathrm{H}), 2.0 .2-2.04(\mathrm{~m}, 4 \mathrm{H}), 2.12-2.20(\mathrm{~m}, 1 \mathrm{H})$, 2.28-2.35 (m, $1 \mathrm{H}), 2.76-2.78(\mathrm{~m}, 2 \mathrm{H}), 3.79(\mathrm{~s}, 3 \mathrm{H}), 4.67-4.78(\mathrm{~m}, 1 \mathrm{H}), 6.24(\mathrm{~d}, J=7.8 \mathrm{~Hz}, 1 \mathrm{H}) .{ }^{13} \mathrm{C} \mathrm{NMR}$ $\left(100 \mathrm{MHz}, \mathrm{CDCl}_{3}\right) \delta: 12.0,18.3,20.8,21.3,22.3,23.3,24.1,26.3,26.5,26.9,28.1,31.4,31.5,32.2$, 
33.1, 34.5, 35.0, 35.3, 35.7, 40.1, 40.3, 41.8, 42.7, 50.5, 52.6, 56.0, 56.4, 71.4, 74.2, 77.4, 78.6, 170.4, 170.9, 173.1. MS (ESI, $m / z): \mathrm{C}_{32} \mathrm{H}_{50} \mathrm{NO}_{5}[\mathrm{M}+\mathrm{H}]^{+}$calc. 528.3 found 528.3

5.6.2. Methyl 2-((R*)-4-((3R,5R,8R,9S,10S,13R,14S,17R)-3-acetoxy-10,13-dimethylhexadecahydro-1Hcyclopenta[a]phenanthren-17-yl)pentanamido)-3-(1-(4-hydroxybutyl)-1H-1,2,3-triazol-4-

yl)propanoate (7)

Prepared from alkyne 6 and 4-azido-1-butanol according to the general procedure for triazole synthesis in $90 \%$ yield. ${ }^{1} \mathrm{H}$ NMR $\left(400 \mathrm{MHz}, \mathrm{CDCl}_{3}\right) \delta: 0.62(\mathrm{~s}, 3 \mathrm{H}), 0.89-0.91(\mathrm{~m}, 6 \mathrm{H}), 1.00-1.13(\mathrm{~m}, 5 \mathrm{H})$, 1.12-1.14 (m, 1H), 1.21-1.26 (m, 3H), 1.29-1.45 (m, 8H), 1.49-1.57 (m, 4H), 1.65-1.87 (m, 7H), 1.93$1.96(\mathrm{~m}, 1 \mathrm{H}), 2.02(\mathrm{~s}, 3 \mathrm{H}), 2.06-2.13(\mathrm{~m}, 1 \mathrm{H}), 2.21-2.30(\mathrm{~m}, 1 \mathrm{H}), 3.21(\mathrm{~d}, J=5.4 \mathrm{~Hz}, 2 \mathrm{H}), 3.48(\mathrm{~s}$, $1 \mathrm{H}), 3.63(\mathrm{t}, J=6.1 \mathrm{~Hz}, 2 \mathrm{H}), 3.71(\mathrm{~s}, 3 \mathrm{H}), 4.37(\mathrm{t}, J=7.0 \mathrm{~Hz}, 2 \mathrm{H}), 4.67-4.75(\mathrm{~m}, 1 \mathrm{H}), 4.90-4.93(\mathrm{~m}, 1 \mathrm{H})$, $6.58(\mathrm{~d}, J=8.0 \mathrm{~Hz}, 1 \mathrm{H}), 7.38(\mathrm{~s}, 1 \mathrm{H}) .{ }^{13} \mathrm{C} \mathrm{NMR}\left(100 \mathrm{MHz}, \mathrm{CDCl}_{3}\right) \delta: 12.0,18.2,20.7,21.4,23.3,24.1$, 26.2, 26.5, 26.8, 26.9, 27.8, 28.1, 29.1, 31.4, 32.1, 33.2, 34.4, 34.9, 35.3, 35.4, 35.7, 40.1, 40.3, 41.8, 42.6, 50.0, 50.1, 51.6, 52.4, 56.0, 56.4, 61.3, 74.3, 122.1, 142.8, 170.7, 171.7, 173. 8. MS (ESI, $\mathrm{m} / \mathrm{z})$ : $\mathrm{C}_{36} \mathrm{H}_{59} \mathrm{~N}_{4} \mathrm{O}_{6}[\mathrm{M}+\mathrm{H}]^{+}$calc. 643.4 found 643.4 .

5.6.3. Methyl 2-((R*)-4-((3R,5R,8R,9S,10S,13R,14S,17R)-3-acetoxy-10,13-dimethylhexadecahydro-1Hcyclopenta[a]phenanthren-17-yl)pentanamido)-3-(1-(4-(methylsulfonyloxy)butyl)-1H-1,2,3-triazol-4yl)propanoate (8)

Compound 7 (100 mg, $0.16 \mathrm{mmol}$ ) was dissolved in anhydrous DCM $(1 \mathrm{~mL})$ at $0{ }^{\circ} \mathrm{C}$. TEA ( $32 \mu \mathrm{L}, 0.23$ $\mathrm{mmol}$ ) was added followed by mesylchloride $(18 \mu \mathrm{L}, 0.23 \mathrm{mmol})$. The reaction was stirred at $0{ }^{\circ} \mathrm{C}$ for 4 hours (complete conversion by TLC analysis). A saturated $\mathrm{NaHCO}_{3}$ solution ( $1 \mathrm{~mL}$ ) was added, the mixture was extracted with $\mathrm{DCM}(2 \times 3 \mathrm{~mL})$ and the organic phase was dried over $\mathrm{MgSO}_{4}$. The title compound was obtained after FCC (Hex/ACOET 8:2) to give the title compound as a white foam in quantitative yield.

${ }^{1} \mathrm{H} \mathrm{NMR}\left(400 \mathrm{MHz}, \mathrm{CDCl}_{3}\right) \delta: 0.63(\mathrm{~s}, 3 \mathrm{H}), 0.90-0.92(\mathrm{~m}, 6 \mathrm{H}), 10.1-1.46(\mathrm{~m}, 19 \mathrm{H}), 1.51-1.56(\mathrm{~m}, 2 \mathrm{H})$, $1.61(\mathrm{~s}, 1 \mathrm{H}), 1.66-1.84(\mathrm{~m}, 8 \mathrm{H}), 1.94-1.80(\mathrm{~m}, 1 \mathrm{H}), 2.02-2.21(\mathrm{~m}, 6 \mathrm{H}), 2.22-2.32(\mathrm{~m}, 1 \mathrm{H}), 3.01(\mathrm{~s}, 3 \mathrm{H})$, 3.18-3.28 (m, 2H), $3.71(\mathrm{~s}, 3 \mathrm{H}), 4.23((\mathrm{t}, J=6.1 \mathrm{~Hz}, 2 \mathrm{H}), 4.38(\mathrm{t}, J=6.9 \mathrm{~Hz}, 2 \mathrm{H}), 4.67-4.75(\mathrm{~m}, 1 \mathrm{H})$, 4.90-4.94 (m, 1H), $6.56(\mathrm{~d},, J=8.4 \mathrm{~Hz}, 1 \mathrm{H}), 7.35(\mathrm{~s}, 1 \mathrm{H}) .{ }^{13} \mathrm{C} \mathrm{NMR}\left(100 \mathrm{MHz}, \mathrm{CDCl}_{3}\right) \delta: 12.0,18.3,20.8$, 21.5, 23.3, 24.1, 26.1, 26.3, 26.6, 27.0, 27.8, 31.5, 32.2, 33.3, 34.6, 35.0, 35.4, 35.5, 35.8, 40.1, 40.3, $41.9,42.7,49.4,51.5,52.5,56.0,56.4,68.8,74.4,122.1,143.2,170.7,171.7,173.6$. MS (ESI, $m / z)$ : $\mathrm{C}_{37} \mathrm{H}_{61} \mathrm{~N}_{4} \mathrm{O}_{8} \mathrm{~S}[\mathrm{M}+\mathrm{H}]^{+}$calc. 721.4 found 721.4 .

\subsection{Cell culture and BSEP membrane vesicles}

HEK293-OATP1B1, HEK293-OATP1B3 and HEK293-MOCK transfected cells were grown by the AstraZeneca's cell culture facility in Alderley Park, UK on $225 \mathrm{~cm}^{2}$ Costar ${ }^{\circledast}$ cell culture flasks at $37^{\circ} \mathrm{C}$ in a humidified $5 \% \mathrm{CO}_{2}$ atmosphere using DMEM medium supplemented with $10 \%(\mathrm{v} / \mathrm{v})$ foetal calf serum, $1 \mathrm{mg} / \mathrm{mL}$ of geneticin, and $4 \mathrm{mM}$ of L-glutamine. The cells were plated 48 hours before assaying in BD Biocoat ${ }^{\mathrm{TM}}$ Poly-D-lysine 24 -well plates at a density 0.25 million cells per well.

A recombinant cell line expressing NTCP, CHO-NTCP and parental $\mathrm{CHO}$ cell lines were obtained from Cell Bank of AstraZeneca, Alderley Park, UK. The CHO-NTCP and CHO parental cells were grown on 75 $\mathrm{cm}^{2}$ or $225 \mathrm{~cm}^{2}$ Costar ${ }^{\circledast}$ cell culture flasks at $37^{\circ} \mathrm{C}$ in a humidified $5 \% \mathrm{CO}_{2}$ atmosphere using Dulbecco's Modified Essential Medium (DMEM) medium supplemented with $10 \%(\mathrm{v} / \mathrm{v})$ foetal calf serum, $4 \mathrm{mM}$ of L-glutamine. CHO-NTCP cell cultures additionally included $1 \mathrm{mg} / \mathrm{mL}$ of geneticin during the growth of cultures. The cells were maintained sub-confluent and split twice weekly, 1:3 - 1:10 depending on 
their density. The cells were cultured in BD Biocoat ${ }^{\mathrm{TM}}$ Poly-D-lysine 24-well multiwell plates for assaying and were plated 72 hours prior to assaying at a cell density of 0.25 million cells per well.

Human BSEP membrane vesicles (derived from plasma membrane of transfected Spodoptera frugiperda (Sf) 21 cells expressing most common variant of human BSEP) were prepared at Reagents \& Assay Development group in Discovery Sciences, AstraZeneca R\&D (Alderley Park, UK).

\subsection{Transport study}

Cellular uptake of tritium labeled compounds was measured using monolayer cultures of HEK293-OATP1B1, HEK293-OATP1B3, HEK293-MOCK, CHO-NTCP and CHO parental cells grown on 24well plates as described previously, ${ }^{6,22}$ with specific adaptation as described in the following sections. The tritiated test compound was diluted in HBS (pH adjusted to 7.4) to obtain $30 \mathrm{~mL}$ of $0.05 \mu \mathrm{M}$ working solution (about $37 \mathrm{KBq} \mathrm{mL}^{-1}$ ) which was warmed to $37{ }^{\circ} \mathrm{C}$ prior to assays. Concentration dependent uptake of the potential PET tracer was studied over a range of six concentrations having activity of about $37 \mathrm{KBq} \mathrm{mL}^{-1}$. The culture media was removed from the 24-well plates containing the desired cell line at about $100 \%$ confluence. Cells were washed three times $(3 \times 0.5 \mathrm{~mL})$ with prewarmed $\left(37^{\circ} \mathrm{C}\right) \mathrm{HBS}$ solution ( $\mathrm{pH}$ adjusted to 7.4$)$. The medium was carefully removed by aspiration using a vacuum pump. The third wash of HBS solution was left on the cells and the plate was warmed on a bench top incubator at $37^{\circ} \mathrm{C}$ for 15 minutes before starting the uptake assays. The HBS solution was removed from the wells immediately prior to start of the assay.

To start the uptake assay, $0.5 \mathrm{~mL}$ of pre-warmed test compound solution were added to the wells (experiments were performed in triplicate) by using a multipipette and the plate was returned to the bench incubator at $37{ }^{\circ} \mathrm{C}$. At the designed time, the solution containing the test compound was carefully removed from the wells by aspiration and the cells were washed three times $(3 \times 1 \mathrm{~mL})$ with ice-cold HBS solution ( $\mathrm{pH} 7.4)$. Cells were lysed by adding Triton $\mathrm{X}-100(0.5 \mathrm{~mL}, 0.1 \% \mathrm{v} / \mathrm{v})$ to each well. The plates were gently shaken for $30 \mathrm{~min}$ at room temperature and the lysate $(200 \mu \mathrm{l})$ was transferred into $10 \mathrm{~mL}$ glass scintillation vials containing Ultima Gold ${ }^{\circledR}$ scintillation cocktail $(5 \mathrm{~mL})$ for liquid scintillation counting. The plates containing the cell lysate were stored at $-20^{\circ} \mathrm{C}$ for protein analysis. The amount of protein content per well was determined as a mean of six wells per plate using the Pierce ${ }^{\circledR}$ BCA Protein assay kit.

Transport of tritiated test compounds in HEK293-OATP1B1 and HEK293-MOCK transfected cells was assessed in the presence and absence of the inhibitor rifamycin $\mathrm{SV}$ in a range of 6-concentrations with the aim to determine $\mathrm{IC}_{50}$ values for the inhibition of OATP1B1-mediated transport.

Rifamycin SV was dissolved in DMSO to obtain a primary $10 \mathrm{mM}$ stock solution which was diluted with pre-warmed HBS solution ( $\mathrm{pH} 7.4$ ) to obtain six pre-incubation solutions of rifamycin SV at 100, 10, 1, $0.1,0.01,0.001 \mu \mathrm{M}$. Content of DMSO was kept constant at $1 \%(\mathrm{v} / \mathrm{v})$. To obtain the six co-incubation solutions, the secondary stock solutions of rifamycin SV were diluted 100 times with HBS (pH adjusted to 7.4 ) containing $0.05 \mu \mathrm{M}\left(37 \mathrm{KBq} \mathrm{mL}^{-1}\right.$ ) of the tritiated substrate.

The culture media was removed from the 24-well plates containing HEK293-OATP1B1 cells at about $100 \%$ confluence. Cells were washed three times $(3 \times 0.5 \mathrm{~mL})$ with pre-warmed $\left(37^{\circ} \mathrm{C}\right) \mathrm{HBS}$ solution $(\mathrm{pH}$ 7.4) and replaced by the pre-incubation solutions containing the inhibitor. The plate was incubated at $37^{\circ} \mathrm{C}$ for 15 minutes. After this time, the pre-incubation solutions were removed and the uptake was initiated by adding to the working solution containing the inhibitor at $0.001,0.01,0.1,1$, $10,100 \mu \mathrm{M}$ and the labeled substrate. The plate was returned to the incubator and after 8 minutes of incubation the working solutions were removed from the wells and the cells treated as previously described. 


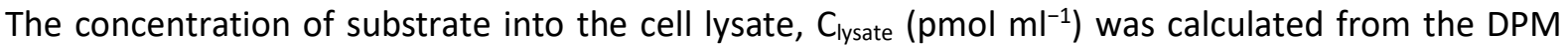
(disintegration per minute) values obtained by liquid scintillation counting of the samples from the specific activity SA (in KBq pmol-1) of the test solution using the equation (1)

$C_{\text {lysate }}=\frac{\frac{D P M_{\text {sample }}}{60000}}{S A} \quad$ (equation 1)

where 60000 is the conversion factor between disintegration per minute (DPM) and KBq.

The uptake rate $U$ was calculated with the equation (2), where $U$ is the rate of uptake of substrate in the cells ( $\left.\mathrm{pmol} \mathrm{min}{ }^{-1} \mathrm{mg}^{-1}\right) ; \mathrm{T}$ is the time of incubation $(\mathrm{min}) ; \mathrm{P}$ is the mean protein content $\left(\mathrm{mg} \mathrm{ml}^{-1}\right)$

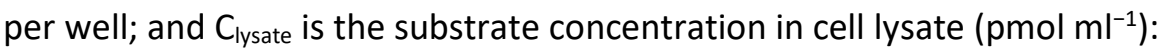

$U=\frac{C_{l y s a t e}}{T \cdot P} \quad$ (equation 2)

The net TRANSPORTER-mediated substrate transport $\mathrm{U}_{\text {TRANSPORTER }}\left(\mathrm{pmol} \mathrm{min}^{-1} \mathrm{mg}^{-1}\right.$ ) was determined as the difference between the uptake rate in TRANSPORTER-expressing cells (UTRANSPORTER-expressing cell) and MOCK-cells ( $\mathrm{U}_{\text {Mock cell) }}$ (equation 3 ):

$U_{\text {TRANSPORTER }}=U_{\text {TRANSPORTER expressing cell }}-U_{\text {MOCK cell }}$ (equation 3)

The influx or uptake ratio, defined as the ratio of the uptake rate in TRANSPORTER-expressing cells ( $\left.U_{\text {TRANSPORTER-expressing cell }}\right)$ and MOCK-cells $\left(\mathrm{U}_{\text {MOcK cell }}\right)$, was calculated according to equation 4and its uncertainty (SUptake Ratio) according to equation $\mathbf{5}$ :

Uptake Ratio $=\frac{U_{\text {TRANSPORTER expressing cell }}}{U_{\text {MOCK cell }}} \quad$ (equation 4)

SUptake Ratio $=$ Uptake Ratio $\cdot \sqrt{\left(\frac{S D U_{T R A N S P O R T E R \text { expressing cell }}}{U_{\text {TRANSPORTER expressing cell }}}\right)^{2}+\left(\frac{S D U_{M O C K \text { cell }}}{U_{\text {MOCK cell }}}\right)^{2}}$ (equation 5)

Where SD represents the standard deviation $(n=3)$. To determine if data sets obtained for the two cell lines were significantly different, Student's $t$-test (Microsoft ${ }^{\circledR}$ Excel 2013) was applied.

GraphPad Prism (Version 6) (Michalis-Menten equation) was used to determine apparent $\mathrm{K}_{\mathrm{m}}$ and $V_{\max }$ by plotting $U_{\text {TRANSPORTER }}$ ( $\mathrm{pmol} \mathrm{min}^{-1} \mathrm{mg}^{-1}$ ) against substrate concentration.

To calculate the concentration of inhibitor that produces half-maximal inhibition $\left(\mathrm{IC}_{50}\right)$ of transporter activity, UATP1B1 was plotted as a percentage of control probe substrate (100\% OATP1B1 activity was assumed when no inhibitor was present) against inhibitor concentration. Transporter activity (\% of control) is then calculated according to the following formula:

$\%$ OATP $1 B 1$ ACTIVITY $=\frac{z}{y} \cdot 100 \quad$ (equation6)

where $z$ is the OATP1B1 uptake of the probe in the presence of the inhibitor, $y$ is the OATP1B1 uptake of the probe in the absence of the inhibitor.

An IC 50 value was obtained using a four-parameter logistic model (XLFit 5, Model 201) or any other appropriate model if needed:

$y=a+\frac{(b-a)}{\left(1+10^{\left((\log c-x)^{*} d\right)}\right)} \quad$ (equation 7) 
where $y$ is the \% control activity and $x$ is the logarithm of concentration of inhibitor, $a$ and $b$ are the vehicle and positive control and are locked to 0 and 100 , respectively; $c$ is the $\mathrm{IC}_{50}$ and $\mathrm{d}$ is the Hill slope of the curve.

In order to understand the contribution of passive diffusion and the contribution of specific transporter OATP1B1 in the uptake of the PET probe compounds in HEK293-OATP1B1 cells, the OATP1B1-intrinsec clearance (or intrinsic capacity) $\mathrm{Cl}_{\text {int, OATP1B1 }}$ and passive diffusion clearance $\mathrm{P}_{\text {diff }}$ were calculated by (equations 8-7)

$C l_{\text {int, } O A T P 1 B 1}=\frac{V_{\max }}{K_{m}} \quad$ (equation 8)

$C l_{\text {diff }}=\frac{U_{M O C K}}{C} \quad$ (equation 9)

where $V_{\max }$ is the maximum rate of uptake, $\mathrm{K}_{\mathrm{m}}$ is the Michaelis-Menten constant, $\mathrm{U}_{\text {Mock }}$ is the uptake measured in HEK293-MOCK cells and $C$ is the concentration of the substrate.

Transport in BSEP-expressing membrane vesicles in the presence and absence of ATP was determined as described previously. ${ }^{12,23}$ Uptake solutions contained $1 \%(\mathrm{v} / \mathrm{v})$ DMSO containing the radiolabeled compound and the appropriate concentration of the corresponding non-radiolabeled compound and membrane vesicles in uptake buffer (HEPES/Tris pH 7.4: $25 \mathrm{mM}$; $\mathrm{KNO}_{3}: 250 \mathrm{mM}$; Sucrose: $125 \mathrm{mM}$; $\left.\mathrm{Mg}\left(\mathrm{NO}_{3}\right)_{2}: 31 \mathrm{mM}\right)$. The $2 \mu \mathrm{l}$ of test compound was added to the 96-well PCR assay plate followed by $50 \mu \mathrm{l}$ of 2 -fold concentrated uptake buffer with ATP or AMP. The assay plate is kept on the heating block $\left(37^{\circ} \mathrm{C}\right)$ and incubated for $3 \mathrm{~min}$. Reaction was initiated by addition of $48 \mu$ l vesicle suspension per well. After 5 min incubation time $80 \mu$ of the reaction mixture was transferred to the filter-plate containing $150 \mu \mathrm{l}$ stop buffer (Sucrose: $50 \mathrm{mM}$; KCl: mM, 100mM; HEPES/Tris pH 7.4: $10 \mathrm{mM}$; Taurocholate: $0.1 \mathrm{mM}$; EDTA pH 7.4: $5 \mathrm{mM}$ ). Filter-plate was transferred to the vacuum manifold and vacuum applied to trap the vesicles in the filter. Washed vesicles 4 times with $150 \mu$ stop buffer, aspirating between each washing step. Filterplate was dried over night at room temperature. $150 \mu \mathrm{l}$ of OptimaGold $\mathrm{F}$ was added per well and incubated for $10 \mathrm{~min}$ and plate sealed with TopSeal adhesive film. Radioactivity was measured on the Microbeta2 (Perkin Elmer, UK).

The mean counts per minute (CPM) from three replicate wells containing an aliquot of the original uptake solution (containing buffer and vesicles) was determined and used to calculate the CPM/pmol normalisation factor:

$\frac{C P M}{p m o l}=\frac{\text { Total CMP }}{(\text { Total } \mu \text { l aliquot }) \cdot(\text { Total } \mu M \text { of radiolabelled compound })}$ (equation 10)

Where: Total CPM was the mean value of wells containing original uptake solution Total $\mu \mathrm{l}$ of aliquot was the volume of original uptake solution Total $\mu \mathrm{M}$ of radiolabeled compound was the concentration in the uptake solution prior to initiation of the incubation

The CPM of each test sample well was determined and divided by the CPM/pmol normalisation factor to calculate the amount (pmol) of compound taken up by the vesicles. This amount was divided by the incubation time $(\mathrm{min})$ and the protein amount in the incubation $(\mathrm{mg})$ to give the uptake activity ( $\mathrm{pmol} / \mathrm{min} / \mathrm{mg}$ ). Mean ( $\mathrm{n}=3$ wells) net BSEP transport activity was determined by subtracting 
transport in BSEP-transporter vesicles in the presence of ATP to that of transport in the presence of AMP. All experiments above were performed in triplicates at single occasion.

\subsection{Radiosynthesis of $\left[{ }^{18} \mathrm{~F}\right]$-LCATD}

Radiosynthesis, purification and formulation steps were performed in an Eckert \& Ziegler ModularLab system equipped with semipreparative HPLC. $\left[{ }^{18} \mathrm{~F}\right]$ Fluoride ( $\left.16 \mathrm{GBq}\right)$ was delivered from the cyclotron into a stock vial and then separated from the $\left[{ }^{18} \mathrm{O}\right] \mathrm{H}_{2} \mathrm{O}$ by means of a Chromafix PS-HCO3-ion exchange cartridge (Waters). $\left[{ }^{18} \mathrm{~F}\right]$ Fluoride was then eluted with the solution of $\mathrm{K}_{2} \mathrm{HPO}_{4}(5 \mathrm{mg}$ in $0.5 \mathrm{~mL}$ of sterile water) and collected in the reactor, followed by the solution of Kryptofix $\mathrm{K} 222$ (15 mg in $1 \mathrm{~mL}$ of anhydrous $\mathrm{CH}_{3} \mathrm{CN}$ ). A first drying cycle was accomplished by heating at $95{ }^{\circ} \mathrm{C}$ under both vacuum and helium flow (400 seconds) and then under vacuum only (150 seconds) before delivering an additional amount of anhydrous $\mathrm{CH}_{3} \mathrm{CN}$. The drying process was repeated and the solution of mesylate precursor 8 (5 mg in $1 \mathrm{~mL}$ of anhydrous $\mathrm{CH}_{3} \mathrm{CN}$ ) was then delivered into the reactor containing the $\left[{ }^{18} \mathrm{~F}\right] \mathrm{KF}-\mathrm{K} 222$ dry complex. The mixture was heated at $90{ }^{\circ} \mathrm{C}$ for 15 minutes. The reactor was cooled to $40{ }^{\circ} \mathrm{C}$ before adding the sodium hydroxide solution $(0.5 \mathrm{~mL}, 2 \mathrm{M}$ in $50 \%$ aqueous methanol) which was allowed to react for 10 minutes. After the hydrolysis step, the crude reaction mixture was neutralized with $2 \mathrm{M}$ $\mathrm{HCl}(0.5 \mathrm{~mL})$ and pumped into a vial containing the $\mathrm{HPLC}$ eluent $\left(\mathrm{PBS} / \mathrm{CH}_{3} \mathrm{CN} 60: 40,1.5 \mathrm{~mL}\right)$. The mixture (about $3 \mathrm{~mL}$ ) was then loaded in the $5 \mathrm{~mL} \mathrm{RP-HPLC} \mathrm{loop} \mathrm{and} \mathrm{then} \mathrm{injected} \mathrm{in} \mathrm{the} \mathrm{Phenomenex}$ Luna C18 column ( $5 \mu \mathrm{m}, 250 \times 10 \mathrm{~mm}, 100 \AA$ ) , which was eluted with PBS/CH ${ }_{3} \mathrm{CN}$ 60:40 (5 mL min-1 flow). The peak corresponding to the desired product was collected in a vial containing $50 \mathrm{~mL}$ of distilled water. The diluted solution of pure $\left[{ }^{18} \mathrm{~F}\right]$-LCATD $\left(\left[{ }^{18} \mathrm{~F}\right]-4 \mathrm{c}\right)$ was then flushed through a C18 SPE cartridge Oasis ${ }^{\circledR}$ HLB Plus (Waters) in order to trap the tracer. The cartridge was then eluted with absolute ethanol $(0.8 \mathrm{~mL})$ and the resulting $\left[{ }^{18} \mathrm{~F}\right]$-LCATD was passed through a sterile filter and finally delivered into a vial, placed in a second hot cell, containing $7.2 \mathrm{~mL}$ of sterile PBS. Up to $2 \mathrm{GBq}$ of injectable solution of $\left[{ }^{18} \mathrm{~F}\right]$-LCATD were obtained $\left(8 \mathrm{~mL}\right.$, up to $\left.250 \mathrm{MBq} \mathrm{mL}{ }^{-1}\right)$. The total synthesis, purification and formulation time was about 90 minutes. The tracer was obtained in $25 \pm 5 \%(n=5)$ decay corrected radiochemical yield. HPLC analysis of the formulated product confirmed the identity (co-injection with cold reference material) and the purity of the tracer (RCP >99\%). Attempts to measure the specific activity of $\left[{ }^{18} \mathrm{~F}\right]$-LCATD failed due to the low UV absorbance of the tracer.

\subsection{PET/CT imaging experiment- pilot study}

The animal experiment was performed according to the University's Code of Practice on the Use of Animals in Research as well as the legal requirements of the Animals Act 1986 and Home Office Code of Practice guidance. PET scans were performed with a small-animal PET/CT scanner (ARGUS-Sedecal, Spain) housed in a temperature-controlled suite. The scanner has two $11.8 \mathrm{~cm}$ diameter rings of photoswich detectors coupled to position sensitive photomultiplier tubes, giving a $4.8 \mathrm{~cm}$ axial field of view (FOV). A female Sprague-Dawley (SD) rat (207g) was provided with standard food and water ad libitum in a temperature and light-controlled environment. The animal was cannulated (Venisystem Butterfly, Abbott Ireland) in the tail vein for tracer injection under general anaesthesia with isoflurane (IsoFlo $100 \% \mathrm{w} / \mathrm{w}$, Abbott Laboratories Ltd) $2.5 \%$ ( $2 \mathrm{~L} \mathrm{~min}-1$ oxygen flow). At the start of the scan $\left[{ }^{18} \mathrm{~F}\right]$-LCATD $4 \mathrm{c}(5.89 \mathrm{MBq})$ was injected as a single bolus and the administered radioactivity was measured as net counts in the cannula before and after the injection with an ionization chamber (Capintec CRC-15PET; Ramsey, New Jersey). Emission scans in 3D list-mode were acquired for 30 minutes (with a FOV encompassing part of the thorax and the intestine) followed by a 5 minutes CT 
scan. At the end of the imaging experiment, the animal was sacrificed under anaesthesia (neck dislocation).

PET acquisitions were obtained with an energy window set to 250 - $700 \mathrm{keV}$ and corrections for deadtime, activity decay, attenuation, random and scatter counts were applied (using the manufacturer' software). The dynamic images were obtained by sorting the list mode data into the following time frames: $6 \times 10 \mathrm{~s}, 8 \times 30 \mathrm{~s}, 10 \times 60 \mathrm{~s}, 3 \times 300 \mathrm{~s}$, and images were reconstructed with a FORE/2D-OSEM reconstruction algorithm (provided by the manufacturer). Sampling at shorter intervals during early time-points enabled to detect rapid increments of tracer uptake in the liver and intestine. Longer time frames at later time-points from the injection time showed the amounts of uptake characteristic for the specific PET tracer. Regions of interest (ROIs) corresponding to abdominal aorta, liver and gastrointestinal tract were manually drawn using PMOD software (PMOD Technologies). The stomach was included in the gastrointestinal ROI to include the amount of bile that might have refluxed from the duodenum into the stomach. Due to the limited FOV of the PET scan - which was not enough to cover the lower intestine - in this PET study the activity in the bile might be underestimated.

\section{Appendix A. Supplementary data.}

Supplementary data related to this article (NMR spectra, configuration for the automated radiosynthesis and HPLC profile of $\left[{ }^{18} \mathrm{~F}\right] 4 \mathrm{c}$, 3D image of the three ROls used for analysis of the PET scans) can be found at: XXXXXXXXXXXXXXXXXXX.

\section{Acknowledgements.}

We thank Dr Dana Dawson and Dr Gabriella Baio for support and advice with PET imaging experiments. A.T. gratefully acknowledges SINAPSE (www.sinapse.ac.uk) and AstraZeneca (UK) for co-funding a studentship. P.S. and C.S.E. are employees of AstraZeneca Ltd., UK.

\section{About the authors.}

Corresponding authors:

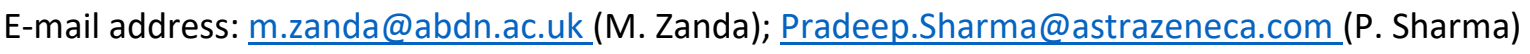

\section{References}

1. Niemi, M.; Pasanen, M. K.; Neuvonen, P. J. Pharmacol. Rev. 2011, 63, 157-181.

2. Shitara, Y.; Maeda, K.; Ikejiri, K.; Yoshida, K.; Horie, T.; Sugiyama, Y. Biopharmaceutics and Drug Disposition 2013, 34, 45-78.

3. Stieger, B. Handb. Exp. Pharmacol. 2011, (201):205-59. doi, 205-259.

4. The International Transporter Consortium Nature Reviews Drug Discovery 2010, 9, 2015-236.

5. Chen, M.; Suzuki, A.; Borlak, J.; Andrade, R. J.; Lucena, M. I. J. Hepatol. 2015, 63, 503-514.

6. Sharma, P.; Butters, C. J.; Smith, V.; Elsby, R.; Surry, D. Eur. J. Pharm. Sci. 2012, 47, 244-255.

7. Kunze, A.; Huwyler, J.; Camenisch, G.; Poller, B. Drug Metab. Dispos. 2014, 42, 1514-1521.

8. Ieiri, I.; Higuchi, S.; Sugiyama, Y. Expert Opinion on Drug Metabolism and Toxicology 2009, 5, 703729. 
9. Stieger, B. Curr. Opin. Lipidol. 2009, 20, 176-181.

10. Keitel, V.; Burdelski, M.; Warskulat, U.; Kuhlkamp, T.; Keppler, D.; Haussinger, D.; Kubitz, R. Hepatology 2005, 41, 1160-1172.

11. Kullak-Ublick, G. A.; Stieger, B.; Hagenbuch, B.; Meier, P. J. Semin. Liver Dis. 2000, 20, 273-292.

12. Dawson, S.; Stahl, S.; Paul, N.; Barber, J.; Kenna, J. G. Drug Metab. Dispos. 2012, 40, 130-138.

13. Kubitz, R.; Droge, C.; Stindt, J.; Weissenberger, K.; Haussinger, D. Clin. Res. Hepatol. Gastroenterol. 2012, 36, 536-553.

14. Frisch, K.; Jakobsen, S.; Sorensen, M.; Munk, O. L.; Alstrup, A. K.; Ott, P.; Hofmann, A. F.; Keiding, S. J. Nucl. Med. 2012, 53, 772-778.

15. For extensive review articles see: a)Testa, A.; Zanda, M.; Elmore, C. S.; Sharma, Mol. Pharm. 2015, 12 (7), 2203-2216 and b) Langer, O. J. Clin. Pharmacol. 2016, 56 (S7),S143-S156.

16. Duane, W. C.; Schteingart, C. D.; Ton-Nu, H. T.; Hofmann, A. F. J. Lipid Res. 1996, 37, 431-436.

17. Anelli, P. L.; Lattuada, L.; Lorusso, V.; Lux, G.; Morisetti, A.; Morosini, P.; Serleti, M.; Uggeri, F. J. Med. Chem. 2004, 47, 3629-3641.

18. Vivian, D.; Cheng, K.; Khurana, S.; Xu, S.; Dawson, P. A.; Raufman, J. P.; Polli, J. E. J. Pharm. Sci. 2014, 103, 3782-3792.

19. Boyd, G. S.; Merrick, M. V.; Monks, R.; Thomas, I. L. J. Nucl. Med. 1981, 22, 720-725.

20. Lutz, J.; Zarafshani, Z. Adv. Drug Deliv. Rev. 2008, 60, 958-970.

21. Testa, A.; Piras M.; Hickey, M. J.; Fleming I.N.; Bushby N.; Lenz E.; Elmore C.S.; Zanda M. Syneltt 2014, 25, 1019-1025.

22. Sharma, P.; Holmes, V. E.; Elsby, R.; Lambert, C.; Surry, D. Xenobiotica 2010, 40, 24-37.

23. Elsby, R.; Smith, V.; Fox, L.; Stresser, D.; Butters, C.; Sharma, P.; Surry, D. Xenobiotica 2011, 41, 764-783.

24. Little, J. M.; Zimniak, P.; Shattuck, K. E.; Lester, R.; Radominska, A. J. Lipid Res. 1990, 31, 615-622.

25. Deo, A. K.; Bandiera, S. M. Drug Metabolism and Disposition 2009, 37, 1938-1947.

26. Sorensen, M.; Munk, O. L.; Orntoft, N. W.; Frisch, K.; Andersen, K. J.; Mortensen, F. V.; Alstrup, A. K.; Ott, P.; Hofmann, A. F.; Keiding, S. J. Nucl. Med. 2016, 57, 961-966.

27. During the preparation of this manuscript, the use of a ${ }^{18} \mathrm{~F}-\mathrm{PET}$ tracer potentially useful to study hepatic transporters has been published: (a) Wanek, T.; Halilbasic, E.; Visentin, M.; Mairinger, S.; Römermann, K.; Stieger, B.; Kuntner, C.; Müller, M.; Langer, O.; Trauner, M. I. J. Pharm. Sci. $2016,105,106-112$. Moreover the ${ }^{18} \mathrm{~F}$ labelling of pitavastatin, a potentially useful tracer for OATPs, was recently achieved: (b) Yagi, Y.; Kimura, H.; Arimitsu, K.; Ono, M.; Maeda, K.; Kusuhara, H.; Kajimoto, T.; Sugiyama, Y.; Saji, H. Org. Biomol. Chem.2015, 13, 1113-1121. To the 
best of our knowledge, no in vivo imaging studies have been published yet. ${ }^{18} \mathrm{~F}$-derivative of chenodeoxycholic acid has also been reported as ligand for the FXR nuclear receptor: (c) Jia, L.; Jiang, D.; Hu, P.; Li, X.; Shi, H.; Cheng, D.; Zhang, L. Nucl. Med. Biol. 2014, 41, 495-500. However, the potential for this tracer to be a substrate of OATPs is not discussed and - since the molecule lacks a negatively charged moiety - it may not be transported by OATPs. Similarly, deoxycholic acid and chenodeoxycholic acid were also labelled with ${ }^{64} \mathrm{Cu}$ as tumor targeting vectors: (d) Chong, H. S.; Chen, Y.; Kang, C. S.; Sun, X.; Wu, N. Bioorg. Med. Chem. Lett. 2015, 25, 10821085.

28. Konig, J.; Cui, Y.; Nies, A. T.; Keppler, D. A. Am. J. Physiol. Gastrointest. Liver Physiol. 2000, 278, G156-64.

29. Konig, J.; Klatt, S.; Dilger, K.; Fromm, M. F. Basic Clin. Pharmacol. Toxicol. 2012, 111, 81-86.

30. Greupink, R.; Dillen, L.; Monshouwer, M.; Huisman, M. T.; Russel, F. G. Eur. J. Pharm. Sci. 2011, 44, 487-496.

31. Byrne, J. A.; Strautnieks, S. S.; Mieli-Vergani, G.; Higgins, C. F.; Linton, K. J.; Thompson, R. J. Gastroenterology 2002, 123, 1649-1658.

32. Karlgren, M.; Vildhede, A.; Norinder, U.; Wisniewski, J. R.; Kimoto, E.; Lai, Y.; Haglund, U.; Artursson, P. J. Med. Chem. 2012, 55, 4740-4763.

33. Chang, C.; Pang, K. S.; Swaan, P. W.; Ekins, S. J. Pharmacol. Exp. Ther. 2005, 314, 533-541. 